\title{
Commonness and rarity pattern of plant species within Terai grassland of northeastern Uttar Pradesh, India
}

\author{
SUMIT SRIVASTAVA, ASHISH DVIVEDI AND R.P. SHUKLA
}

Plant Ecology Laboratory, Department of Botany, D.D.U. Gorakhpur University, Gorakhpur, India. www.ddugu.edu.in/department.php/Botany

Keywords: Community structure, frequency of occurrence, habit groups, habitat fragmentation, native grassland.

\begin{abstract}
We investigated the frequency of occurrence of plant species in grassy landscapes in northeastern Uttar Pradesh, India. Using random quadrats, field assessment was undertaken at 11 sites to sample an area of 333.75 ha, at an overall sampling density of $0.01 \%$. A total of 287 plant species belonging to 183 genera and 53 families was recorded. Of these, 254 species were commonly distributed and 33 species exhibited localized occurrences; according to the rarity classes of Rabinowitz, the latter were classified as rare. One hundred and sixty-five species had large population sizes and 122 species exhibited small population sizes. The most common species, which exhibited high frequency and abundance, were predominantly from Poaceae, Cyperaceae, Papilionaceae, Asteraceae, Scrophulariaceae and Euphorbiaceae. Some species, which are known to have narrow geographical distributions, were locally abundant. Rare species showed restricted as well as localized distributions and were typically sampled at low population densities. The rare occurrences of once frequent and widespread species probably reflect acute fragmentation and shrinkage of specialized habitats as a result of intense cultural activities. Several species are to be considered as threatened. Studies on the status of rare plant species and the processes threatening their survival are urgently required.
\end{abstract}

\section{Resumen}

En ecosistemas de pastizales nativos en el noreste de Uttar Pradesh, India, se midió la frecuencia de aparición de especies vegetales. Las muestras fueron tomadas utilizando el método de cuadrados al azar en 11 sitios de estudio con 31 sitios de muestreo. El área total muestreada fue de 333.75 ha, con una densidad total de muestreo del $0.01 \%$. En total se registraron 287 especies pertenecientes a 183 géneros y 53 familias. De éstas, 254 especies tenían una distribución común mientras 33 especies aparecían con baja frecuencia y en forma localizada; según las clases de rareza de Rabinowitz; estas últimas fueron clasificadas como raras. En poblaciones grandes ocurrieron 165 especies y en poblaciones pequeñas 122 especies. Las especies más comunes, con alta frecuencia y abundancia, fueron predominantemente de las familias Poaceae, Cyperaceae, Papilionaceae, Asteraceae, Scrophulariaceae y Euphorbiaceae. Algunas especies con una distribución geográfica reducida eran localmente abundantes. Especies clasificadas como raras presentaron tanto distribuciones restringidas como localizadas y en general ocurrían a bajas densidades poblacionales. Las ocurrencias raras de especies que antes eran frecuentes y de distribución amplia, probablemente reflejan una aguda fragmentación y reducción de los hábitats especializados, como consecuencia de intensas actividades agrícolas. Varias especies deben considerarse amenazadas y se sugieren estudios sobre los procesos que amenazan su supervivencia.

\section{Introduction}

The structure of plant communities has been conventionally analyzed worldwide (Mueller-Dombois and Ellenberg 1974; Singh and Yadava 1974). The impact of

Correspondence: R.P. Shukla, Plant Ecology Laboratory, Department of Botany, D.D.U. Gorakhpur University, Gorakhpur - 273-009, India.

E-mail: $\underline{\text { drrpshukla@ rediffmail.com }}$ disturbance, described by Pickett and Whyte (1985) as a discrete event along the passage of time that modifies landscape, ecosystem, community and population structure, on the structure and composition of various grassland communities has been observed by various workers (Friedel 1997; Wilsey and Polley 2003), with overexploitation of species and degradation of natural habitats reported to be the major threats to plant species. While excessive removal of plants from the wild, loss of habitat by deforestation and heavy grazing pressure in 
pastures generally threaten the survival of species (Nayar and Sastry 1988), habitat specificity, narrow range of distribution, land use change, introduction of non-native species, habitat fragmentation and degradation of populations, population bottlenecks and genetic drift can also play a part (Weekley and Race 2001; Oostermeijer et al. 2003; Kala 2005).

Many authors have identified and classified the common and rare species of trees and shrubs (Hubbell and Foster 1986; Rabinowitz et al. 1986; Pitman et al. 1999) and emphasized the importance of this process for the conservation of biodiversity in the ecosystem. Information about the frequency of herbaceous plant species, however, is scarce. Daniels et al. (1995) suggested that endemism, elevation, vegetation, habitat and microhabitat specialization influence the relative abundance of plant species, while Pitman et al. (1999) suggest that herbaceous species have smaller geographical ranges than trees. Recently, Magurran and Henderson (2003) and Ulrich and Ollik (2004) proposed the use of composite models to study species abundance to improve ecological understanding of community structuring between common and rare species and predicted high rates of local extinction of rare species.

While a number of workers have studied various phyto-sociological characteristics of grassland communities in different parts of India (Bharucha and Ferreria 1941; Gupta and Sharma 1973) as well as community composition and productivity patterns (Dabadghao and Shankarnarayan 1973; Singh and Yadava 1974; Nautiyal et al. 1997), the so-called Terai grasslands of the plains of northeastern Uttar Pradesh (U.P.) have received little attention, especially in terms of diversity patterns and the loss and gain of species in recent times. They are a very important source of fodder for livestock and represent about $1,280 \mathrm{~km}^{2}$ of the total regional area (Semwal 2005).

The present study was conducted to examine the composition, diversity and frequency patterns of plant species in the regional grassy landscape across the tract between the Sarju River and the foothills of the Himalayas. This region is known to be floristically rich with considerable habitat diversity (Ansari et al. 2006). The empirical relationship between microclimatic conditions of various sites and diversity patterns of respective plant communities was analyzed. The patterns of rarity within the regional flora have been described by using the database of rare species in India as well as the world (Rabinowitz 1981; Rabinowitz et al. 1986; IUCN 2001) in order to emphasize the need to conserve grassland vegetation and their species.

\section{Materials and Methods}

\section{Study area}

The Terai region is a belt of marshy grasslands, savannas, and forests located south of the outer Himalaya foothills, the Siwalik Hills, and north of the IndoGangetic Plain. These plains of northeastern Uttar Pradesh (U.P.) cover 14 districts and occupy 45,760 km². While the climax vegetation is forest and some patches of forest still remain, most of the area has been subjected to recurrent disturbance in the form of clearing, grazing, trampling and burning, resulting in agricultural fields and grassy landscapes, with many rivers, rivulets, nallahs, lakes and ponds. Abandoned arable land reverts to grassland as a result of secondary succession and tends to be stable under the influence of biotic disturbances such as fire, grazing and cutting practices. The regional plain slopes gently from northwest to southeast, and the landscape presents a mosaic of plant communities with varying amounts of grasses and forbs of contrasting life-forms. Composition of the grasslands, developed and maintained by various cultural practices, varies primarily according to the type of soil and available moisture within the upper layer.

\section{Climate}

The climate of the region is typically tropical monsoonal with 3 distinct seasons, viz. summer (March to midJune), monsoon (mid-June to mid-October) and winter (mid-October to February). Average annual rainfall is about $1,814 \mathrm{~mm}$ for the entire study region, with $87 \%$ occurring during the wet summer and monsoon seasons. The number of rainy days per annum is $51 \pm 3.2$ and mean relative humidity is about $87 \%$ in the morning and $74 \%$ in the evening. The eastern Terai plains receive more rainfall over a longer period and possess much richer plant biodiversity than western and southern districts of the state. Mean maximum temperatures during wet summer, winter and dry summer seasons are 35.2, 27.0 and $39.3{ }^{\circ} \mathrm{C}$ and mean minimum temperatures are $26.2,12.1$ and $24.2{ }^{\circ} \mathrm{C}$, respectively (based on climatic data for 2000-2005).

\section{Soil}

The soil of the region is part of the trans-Sarju Plain and comprises Gangetic alluvium brought down by rivers like Ghaghara, Rapti, Rohin and Gandak from the Himalayas in the north. The texture is sandy loam and $\mathrm{pH}$ is about neutral. In the northern area there are a few elevat- 
ed mounds, locally called dhus, which range in size from a few hundred $\mathrm{m}^{2}$ to $4-5 \mathrm{~km}^{2}$ and have brown sandy soil.

\section{Vegetation}

The growing season extends from mid-June to midSeptember, when most species flower and set seed. The general grassland vegetation of northeastern Uttar Pradesh is interspersed with patches of forest, old fields, open pasture, uplands (mounds or dhus), lowlands, orchards, playgrounds and human settlements.

\section{Methods}

We started this study in June 2011 with a general survey of the vegetation and habitat conditions over a vast stretch of grassy landscape of Terai of northeastern Uttar Pradesh, encompassing more than 11 districts and covering about 128,076 ha of a total $36,015 \mathrm{~km}^{2}$ geographical area (Figure 1). Finally, 31 locations, showing marked differences in habitat conditions, were selected and sampled during August 2011 to March 2014 (Annexes Ia and $\mathrm{Ib}$ ). Differences in habitat conditions appeared mainly in the degree of light exposure, soil moisture and soil texture as related to topography and disturbance in the form of fire, grazing, cutting and trampling. Twenty $50 \mathrm{x}$
$50 \mathrm{~cm}$ quadrats were randomly laid out at each location, giving a total of 620 quadrats across 333 ha of the region.

The population densities of species occupying each quadrat were recorded, and total vegetal area of individuals of each species was measured through the chartquadrat method. Based on these values, various phytosociological and diversity indices were derived through conventional methods (Mueller-Dombois and Ellenberg 1974; Magurran 2004). The simple indices were: frequency, density, vegetative cover, their relative values and Importance Value Index (IVI). Several other indices like Simpson's Dominance Index $\left(\mathrm{Cd}=\sum p_{i}^{2}\right)$, Shannon's Diversity Index $\left(\overline{\mathrm{H}}=-\sum p_{i} \ln p_{i}\right)$, Pielou's Evenness Index $(\mathrm{E}=\bar{H} /$ ln S), Abundance:Frequency Ratio (Withford 1948) and Family Importance Value (FIV = relative density + relative diversity + relative vegetative cover) were also derived (Mori et al. 1983) ( $p_{i}$ represents the proportional abundance of the $i$ th species in the community; $\mathrm{S}$ is the species richness; relative diversity of a family is the number of species within the family expressed as a percentage of the total number of species within all families represented in the community). The dominance-diversity curve (species-individual curves or rank-abundance model) was plotted as a log normal distribution model (Magurran 1988).

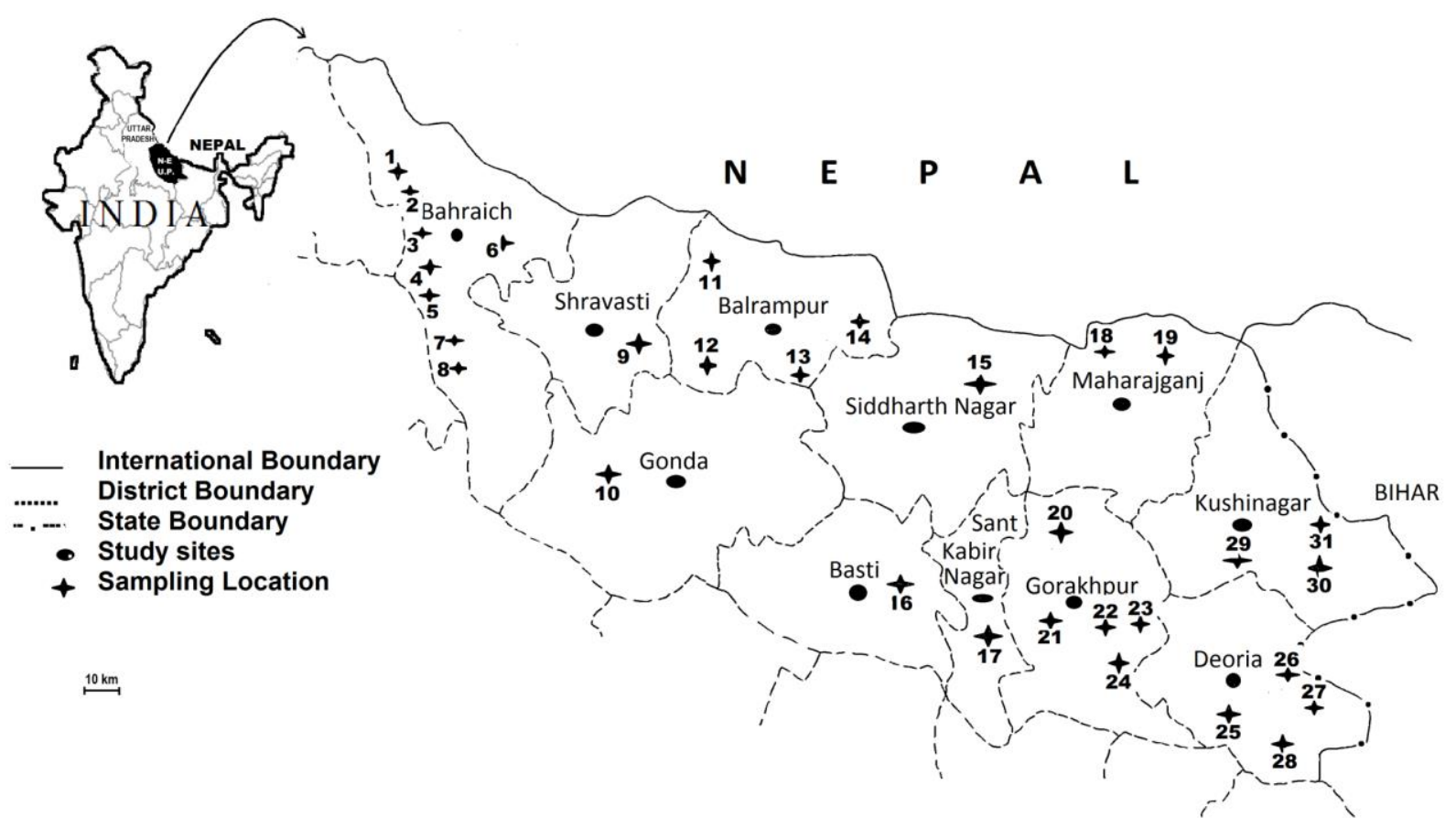

Figure 1: Map showing the study sites and sampling locations (1-31) in the Terai grasslands, northeastern Uttar Pradesh, India. 


\section{Identification of common and rare species}

Rabinowitz's classification scheme (Rabinowitz 1981; Rabinowitz et al. 1986) was used to categorize each of the threatened taxa into 1 of 7 types. They were defined on the basis of the size of their geographic range (wide vs. narrow), habitat specificity (broad vs. restricted) and population size (large, dominant vs. small, scattered). From the combination of these traits, 8 categories were formed to decide commonness vs. rarity of a given species (Tables 1 and 2). For all species one or more of the following 10 items was allocated as a threat to their survival: 1 . urbanization and land development; 2 . agricultural activities; 3 . logging and associated harvest activities; 4. mining and associated habitat destruction; 5. livestock grazing, especially unsustainable and inappropriate grazing; 6. trampling for recreation, resulting in deleterious changes in community composition; 7. overharvesting for horticultural use; 8 . excessive collection for various purposes like medicine; 9. natural disasters such as catastrophic floods and other less-common or miscellaneous threats like fodder, thatch collection etc.; and 10. invasion by alien species (Srivastava et al. 2014).

\section{Results}

The grassy landscape of northeastern Uttar Pradesh is represented by contiguous, small to fairly large patches of grassland vegetation ranging from 1 ha to around 80 ha in size.

\section{Composition of taxa}

The grassland ground-layer vegetation was comprised of grasses and sedges, collectively referred to as graminoids, and forbs or non-grass herbs. A total of 287 spe- cies was recorded, belonging to 183 genera and 53 families; among them, 27 species and 5 families have not yet been identified. Dicotyledons made up $94.5 \%$ of families, $74.1 \%$ of genera and $69.7 \%$ of species, while the remainder were monocotyledons.

\section{Habit groups}

The life-span data of different grassland species showed that about $90 \%$ of species were annuals and the remainder were perennials. The percentage of plant species in different habit groups was: herbs $87 \%$, climbers $10 \%$ and shrubs $3 \%$. Most species ( $>61 \%$ ) were erect annuals, $29 \%$ were prostrate annuals and the remainder were perennials. Among climbers, 39\% were annual twiners, $32 \%$ tendril-bearing and $29 \%$ perennial twiners. There was fairly high species diversity $(\mathrm{H}=3.74)$ and quite low dominance $(\mathrm{Cd}=0.058)$. The mean number of species per genus was 1.62 , with 5.42 per family. The total density was 811.5 individuals $/ \mathrm{m}^{2}$ and evenness was 0.661 .

\section{Species richness}

Among the 6 dominant families, Poaceae was the most common (17.2\% of species), followed by Cyperaceae (11.2\%), Papilionaceae (10.5\%), Asteraceae (9.8\%), Scrophulariaceae $(4.9 \%)$ and Euphorbiaceae $(3.5 \%)$. The remaining $44 \%$ of species represented 46 families, with 20 families represented by only 1 species, 3 by 2 species, 2 by 3 species, 8 by 4 species, 2 by 5 species, 1 by 6 species, 2 by 7 species, 2 by 9 species and 6 families by more than 10 species. In terms of genera, Poaceae, Asteraceae and Papilionaceae were dominant and were represented by 38,19 and 16 genera, respectively.

Table 1. Rarity of plant species based on geographic range, habitat specificity and local population size (after Rabinowitz 1981).

\begin{tabular}{|c|c|c|c|c|}
\hline Geographic range & \multicolumn{2}{|c|}{ Wide } & \multicolumn{2}{|c|}{ Narrow } \\
\hline Habitat specificity & Broad & Restricted & Broad & Restricted \\
\hline Abundance somewhere, large population & Common & Predictable & Unlikely & Endemics \\
\hline Abundance everywhere, small population & \multicolumn{2}{|c|}{ Sparse } & \multicolumn{2}{|c|}{ Non-existent } \\
\hline
\end{tabular}

Table 2. Trait combinations for commonness/rarity of regional rare taxa.

\begin{tabular}{ll}
\hline 1 & Wide geographic range, broad habitat specificity, large population size \\
2 & Wide geographic range, broad habitat specificity, small population size \\
3 & Wide geographic range, restricted habitat specificity, large population size \\
4 & Wide geographic range, restricted habitat specificity, small population size \\
5 & Narrow geographic range, broad habitat specificity, large population size \\
6 & Narrow geographic range, broad habitat specificity, small population size \\
7 & Narrow geographic range, restricted habitat specificity, large population size \\
8 & Narrow geographic range, restricted habitat specificity, small population size \\
\hline
\end{tabular}


The distribution of common and rare plant species among major families (Figure 2) shows that the foremost families in the regional grasslands shared the maximum number of rare plant species. For instance, Papilionaceae had 5 species, followed by Poaceae and Asteraceae (4 species each) and Lamiaceae with 3 species. Scrophulariaceae, Caesalpiniaceae and Boraginaceae families were represented by 2 species each and 12 families by a single species only. The family Apiaceae is economically and medicinally very important but contains the least number of species in the region. Four families, Lobeliaceae, Martyniaceae, Sphenocleaceae and Zygophyllaceae, had only 1 genus each with a single species, viz. Lobelia alsinoides, Martynia annua, Sphenoclea zeylanica and Tribulus terrestris, respectively. The local extinction of these very rare species would mean that the family would no longer be represented in this region.

\section{Abundance distribution}

Abundance is a quantitative indication of patchiness of species. Several common herbaceous species showed hyper-dispersion across grassland vegetation as evident from their density and abundance values. Lindernia diffusa had maximum average density and abundance. Species like Desmodium triflorum, Evolvulus nuтmularis, Imperata cylindrica, Lindernia ciliata and Rungia repens showed abundance values of $>20$ (Table 3 ).

The abundance:frequency (A:F) ratio provides a useful measure to show the degree of clumping or patchiness of species in restricted or localized areas. Table 4 shows the pattern of distribution of grassland species on the basis of A:F ratio, which was highest for erect annual herbs, followed by prostrate annual herbs, with the lowest value for prostrate perennial herbs. The erect annual

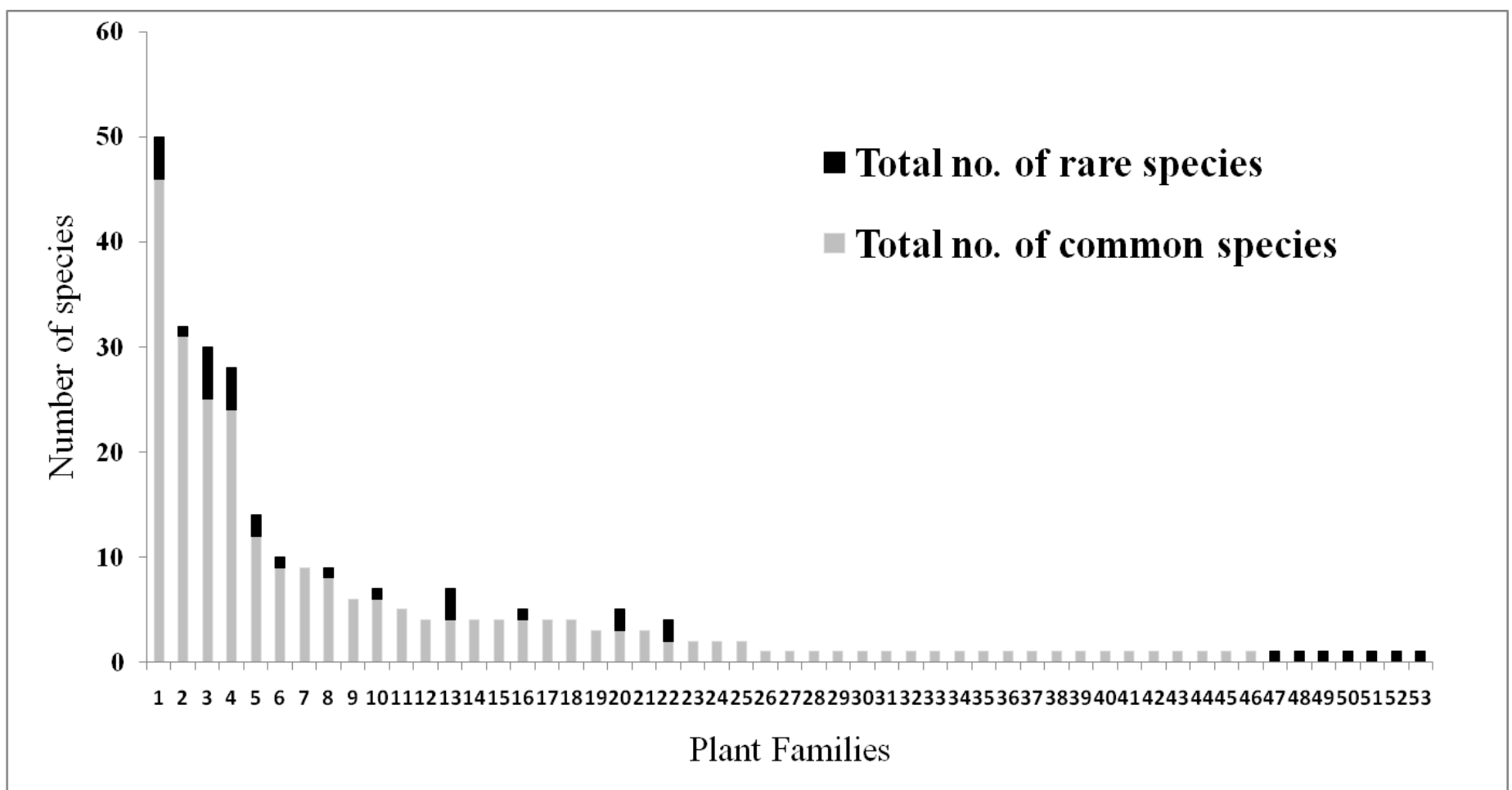

Figure 2. Distribution of plant species among different families of regional grassland vegetation in Uttar Pradesh. The sequence of families is in decreasing order of their species richness. 1. Poaceae, 2. Cyperaceae, 3. Papilionaceae, 4. Asteraceae, 5. Scrophulariaceae, 6. Euphorbiaceae, 7. Malvaceae, 8. Amaranthaceae, 9. Acanthaceae, 10. Convolvulaceae, 11. Unknown, 12. Cucurbitaceae, 13. Lamiaceae, 14. Onagraceae, 15. Polygonaceae, 16. Rubiaceae, 17. Tiliaceae, 18. Verbenaceae, 19. Asclepiadaceae, 20. Caesalpiniaceae, 21. Menispermaceae, 22. Boraginaceae, 23. Cuscutaceae, 24. Lythraceae, 25. Molluginaceae, 26. Aizoaceae, 27. Apocynaceae, 28. Basellaceae, 29. Bignoniaceae, 30. Cannabinaceae, 31. Capparidaceae, 32. Chenopodiaceae, 33. Commelinaceae, 34. Fumariaceae, 35. Moraceae, 36. Nyctanginaceae, 37. Oxalidaceae, 38. Papaveraceae, 39. Polyg alaceae, 40. Portulacaceae, 41. Primulaceae, 42. Ranunculaceae, 43. Solanaceae, 44. Sterculiaceae, 45. Urticaceae, 46.Vitaceae, 47. Amaryllidaceae, 48. Apiaceae, 49. Lobeliaceae, 50. Martyniaceae, 51. Sphenocleaceae, 52. Violaceae, 53. Zygophyllaceae. 
Table 3. Species showing maximum aggregation and hyperdispersion (as evident from their density and abundance values) across the grassy landscape of northeastern Uttar Pradesh. (Based on 620 quadrats each of $0.25 \mathrm{~m}^{2}$ size, laid across 11 districts.)

\begin{tabular}{lcc}
\hline Species & Density & Abundance \\
\hline Desmodium triflorum & 58.2 & 20.5 \\
Evolvulus nummularis & 50.4 & 22.2 \\
Imperata cylindrica & 19.6 & 28.9 \\
Lindernia ciliata & 56.5 & 31.7 \\
Lindernia diffusa & 143.8 & 60.7 \\
Rungia repens & 62.6 & 28.8 \\
\hline
\end{tabular}

Table 4. The range of abundance:frequency (A:F) ratio for species in different posture or growth habit groups across the grassy landscape of northeastern Uttar Pradesh.

\begin{tabular}{lc}
\hline Posture/Habit & Range of A:F ratio \\
\hline Herbs & \\
Erect annuals & $18.6-0.05$ \\
Prostrate annuals & $17.2-0.20$ \\
Erect perennials & $2.33-0.22$ \\
Prostrate perennials & $0.90-0.14$ \\
Climbers & \\
Tendril annuals & $3.37-0.59$ \\
Twining annuals & $6.2-0.53$ \\
Twining perennials & $6.2-0.27$ \\
Shrubs & \\
Erect annuals & $2.23-0.16$ \\
Erect perennials & $1.94-0.18$ \\
\hline
\end{tabular}

herbaceous species with A:F>10 were Hemarthria compressa, Fimbristylis dichotoma, Cynoglossum lanceolatum and Zephyranthus citrina. The lowest A:F ratio was shown by Euphorbia hirta.

\section{Dominance-diversity curve}

The dominance-diversity curves for the regional grassy landscape as an abstract community showed a lognormal distribution of individuals among constituent species (Figure 3). Lindernia diffusa, Rungia repens, Desmodium triflorum and Lindernia ciliata, had the highest number of individuals and formed the top end of the curve. On the other hand, the species which formed the tail end of the curve were Amaranthus spinosus, Crotalaria retusa, Crotalaria pallida, Ludwigia adscendens and Solanum virginianum. The latter species obviously showed rare occurrences.

\section{Population status}

Common species have a large range, wide habitat specificity and large populations. However, a few species have a large range and occur in a wide array of habitats, but in chronically small populations, and are considered quite rare (Rabinowitz et al. 1986). In our observations, a number of plant species, which had a large range and wide habitat specificity, apparently showed small populations due to sampling limitations. As these species

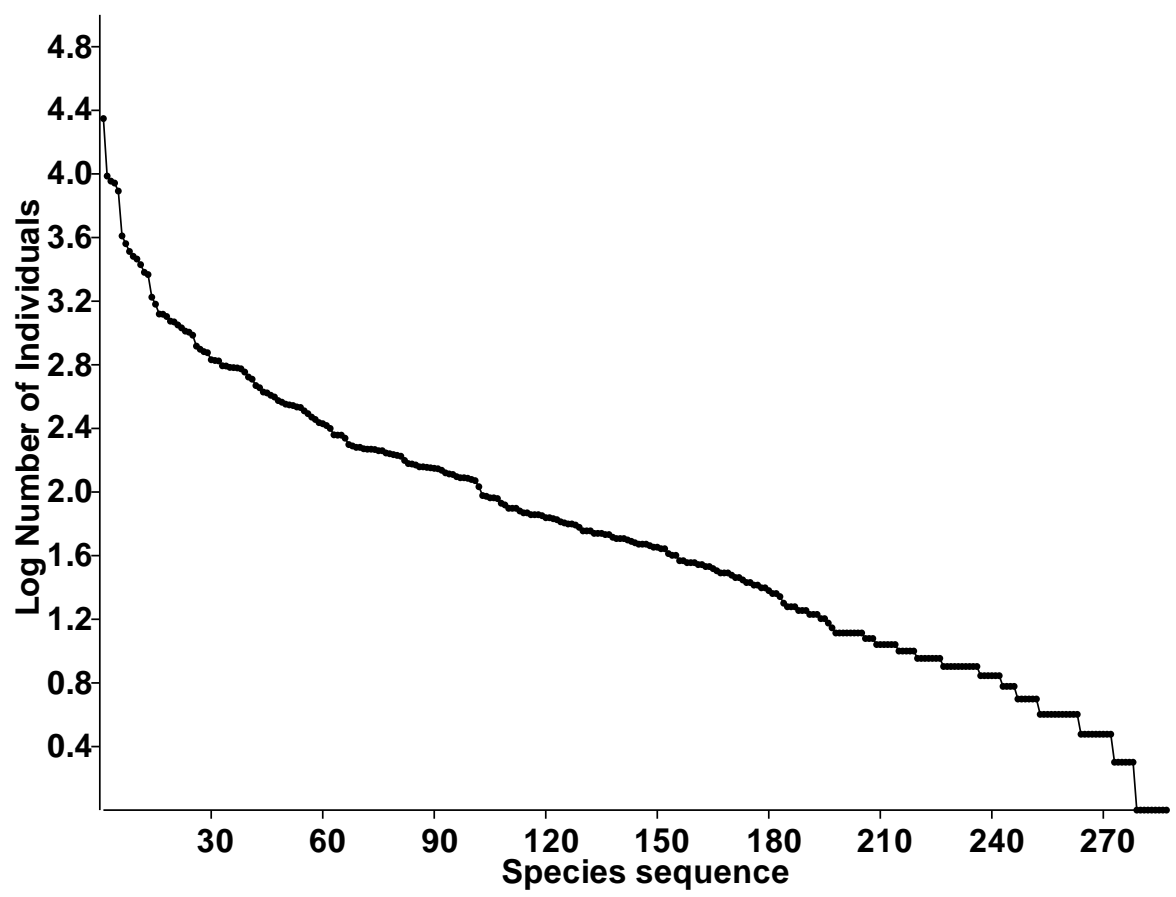

Figure 3. Rank-abundance model (dominance-diversity curve) of the grassy landscape of northeastern Uttar Pradesh. 
Table 5. Number and status of rare and common plant species with different trait combinations across the grassy landscape vegetation of northeastern Uttar Pradesh.

\begin{tabular}{|c|c|c|}
\hline Trait combinations & No. Species & Status \\
\hline $\begin{array}{l}\text { Wide geographic range, broad habitat } \\
\text { specificity, large population size }\end{array}$ & $\begin{array}{l}150 \text { Cynodon dactylon, Desmodium triflorum, Evolvulus nummularis, Imperata } \\
\text { cylindrica, Lindernia ciliata, Lindernia diffusa, Rungia repens and } 143 \text { more } \\
\text { species }\end{array}$ & Common \\
\hline $\begin{array}{l}\text { Wide geographic range, broad habitat } \\
\text { specificity, small population size }\end{array}$ & $\begin{array}{l}104 \text { Glinus oppositifolius, Dentella repens, Crotalaria prostrata, Blumea lacera, } \\
\text { Ammania baccifera, Cissampelos pariera and } 98 \text { more species }\end{array}$ & Common \\
\hline $\begin{array}{l}\text { Wide geographic range, restricted } \\
\text { habitat specificity, large population } \\
\text { size }\end{array}$ & 2 Centella asiatica, Evolvulus alsinoides & Rare \\
\hline $\begin{array}{l}\text { Wide geographic range, restricted } \\
\text { habitat specificity, small population } \\
\text { size }\end{array}$ & 2 Euphorbia thymifolia, Hybanthus linearifolius & Rare \\
\hline $\begin{array}{l}\text { Narrow geographic range, broad hab- } \\
\text { itat specificity, small population size }\end{array}$ & 2 Leucas cephalotus, Leucas aspera & Rare \\
\hline $\begin{array}{l}\text { Narrow geographic range, restricted } \\
\text { habitat specificity, small population } \\
\text { size }\end{array}$ & $\begin{array}{l}15 \text { Baccopa monnieri, Chamaecrista absus, Cyperus niveus, Eragrostis capensis, } \\
\text { Eragrostis cilianensis, Heliotropium ovalifolium, Lobelia alsinoides, } \\
\text { Martynia annua, Cullen corylifolium, Sphenoclea zeylanica, Cajanus } \\
\text { scarabaeoides, Teramnus labialis, Tribulus terrestris, Vernonia sp., } \\
\text { Zephyranthes citrina }\end{array}$ & Rare \\
\hline $\begin{array}{l}\text { Narrow geographic range, broad hab- } \\
\text { itat specificity, large population size }\end{array}$ & 1 Hygrophila auriculata & Rare \\
\hline $\begin{array}{l}\text { Narrow geographic range, restricted } \\
\text { habitat specificity, large population } \\
\text { size }\end{array}$ & $\begin{array}{l}11 \text { Alternanthera pungens, Alysicarpus bupleurifolius, Senna pumila, } \\
\text { Chrysanthellum indicum, Crotalaria calycina, Crotalaria pallida, } \\
\text { Cynoglossum lanceolatum, Hemarthria compressa, Heteropogon contortus, } \\
\text { Perotis indica, Spermacoce pusilla }\end{array}$ & Rare \\
\hline
\end{tabular}

often showed vigorous growth in small patches, distributed across the whole of the range, they could not be considered rare, though their observed traits suggested so. Such an intriguing situation may be common-place in judging the population size of a species as determined by the limitations of method and extent of sampling. Thus, 6 of 8 combinations represent rare and 2 represent common species as evident through this study. Of the total 287 species, 150 showed large range, wide habitat specificity and large populations and 104 species showed large range, wide habitat specificity and small populations (Annex II). Both groups were considered common. The remaining 33 species within 6 different combinations were considered rare (Table 5). Populations of species with habit groups facing a combination of threats have declined within the region (Tables 6 and 7). Thirtythree species showed a maximum of 10 individuals per quadrat and were encountered in $<1 \%$ of total quadrats observed.

Chrysanthellum indicum, Evolvulus alsinoides and Spermacoce pusilla, however, were recorded at only 1 of the 11 sites but there were numerous individuals at this site. Almost all species were exposed to the threats of urbanization and land development, habitat destruction, intense agricultural practices, unmanaged livestock grazing, trampling and other miscellaneous threats. The populations of some of the highly medicinal plants, such as Hygrophila auriculata, Bacopa monnieri, Centella asiatica, Chrysanthellum indicum, Hybanthus linearifolius, Euphorbia thymifolia, Evolvulus alsinoides, Leucas aspera, L. cephalotus, Vernonia sp. and Tribulus

Table 6. Types of threat reducing populations of various plant species to rarity and local extinction across grassy landscapes of northeastern Uttar Pradesh.

\begin{tabular}{ll}
\hline No. & Threat type \\
\hline 1 & Urbanization and land development \\
2 & Agricultural activities \\
3 & Logging and associated harvest activities \\
4 & Mining and associated habitat destruction \\
5 & Livestock grazing, especially unsustainable and inappro- \\
& priate grazing \\
6 & Trampling by stock and humans \\
7 & Over-harvesting for horticultural use \\
8 & Excessive collection for various purposes like medicine \\
9 & and fodder \\
& miscellaneous threats \\
10 & Invasion by alien plants \\
\hline
\end{tabular}


Table 7. Species by habit group facing combinations of threats (numbered as above) which have declined to the level of rarity within the regional grassy landscape in northeastern Uttar Pradesh.

\begin{tabular}{|c|c|c|}
\hline Species & Habit & Combination of threats \\
\hline Alternanthera pungens & Annual herb & $1+4+6+8$ \\
\hline Sphenoclea zeylanica & Annual herb & $1+4+5+6$ \\
\hline Alysicarpus bupleurifolius & Annual herb & $1+4+5+6+8$ \\
\hline Hygrophila auriculata & Perennial herb & $1+2+4+8$ \\
\hline Centella asiatica & Perennial herb & $1+2+4+7+8+10$ \\
\hline Tribulus terrestris & Annual herb & $1+2+4+6+7+8+9$ \\
\hline $\begin{array}{l}\text { Eragrostis capensis, Eragrostis cilianensis, Hemarthria compressa, } \\
\text { Zephyranthes citrina }\end{array}$ & Annual herb & $1+2+4+5+6+8+9$ \\
\hline Heliotropium ovalifolium, Lobelia alsinoides & Annual herb & $1+2+4+5+6+8$ \\
\hline Bacopa monnieri & Perennial herb & $1+2+4+5+7+8+10$ \\
\hline Leucas aspera, Leucas cephalotus & Annual herb & $1+2+6+8+9$ \\
\hline Chamaecrista absus & Annual herb & $1+2+5+6+9$ \\
\hline Euphorbia thymifolia & Annual herb & $1+2+4+8+9$ \\
\hline Vernonia sp. & Annual herb & $1+2+3+4+5+8+9$ \\
\hline $\begin{array}{l}\text { Cajanus scarabaeoides, Crotalaria calycina, Crotalaria pallida, } \\
\text { Cullen corylifolium, Cynoglossum lanceolatum, Cyperus niveus, } \\
\text { Martynia annua, Perotis indica, Senna pumila, Spermacoce pusilla }\end{array}$ & Annual herb & $1+2+4+5+8+9+10$ \\
\hline Heteropogon contortus & Perennial herb & $1+2+4+5+8+9+10$ \\
\hline Teramnus labialis & Annual herb & $1+2+4+5+8+9+10$ \\
\hline Chrysanthellum indicum, Evolvulus alsinoides, Hybanthus linearifolius & Annual herb & $1+2+3+4+6+7+8+9$ \\
\hline
\end{tabular}

terrestris have suffered seriously owing to voracious harvesting from the wild by untrained people. Some rare species of annual upland legumes, such as Alysicarpus bupleurifolius, Alysicarpus longifolius, Senna pumila, Crotalaria calycina, Crotalaria pallida and Cullen corylifolium, require a relatively longer time to produce seeds to complete their annual life cycle as compared with several non-legumes. The period of peak seed fall is often closely followed by high rainfall and moderate water-logging for about a week, and long submergence of fresh seeds may destroy the embryos, rendering them non-viable. On the other hand, the very rare and poor occurrences of some lowland therophytes, such as Cyperus niveus, Lindernia pyxidaria, Lobelia alsinoides and Sphenoclea zeylanica, may be attributed to severe overgrazing just before full blooming and the seedsetting stage. The second most important threat was invasive alien species. Centella asiatica, Baccopa monnieri and Hygrophila auriculata showed very poor populations under these conditions despite efficient modes of non-seed regeneration (Table 8), as invaders have a competitive advantage and readily suppress and replace the native species under stressful environments. Table 9 shows the specific habitats for rare plant species.

Table 8. Mode of regeneration and sprouting efficiency of different rare and most common (with asterisk) plant species of grassy landscapes of northeastern Uttar Pradesh.

\begin{tabular}{lc}
\hline Mode of regeneration & Species \\
\hline Seed only & Alysicarpus bupleurifolius, Chrysanthellum indicum, Crotalaria calycina, Crotalaria pallida, \\
Cullen corylifolium, Cynoglossum lanceolatum, Cyperus niveus, Eragrostis capensis, \\
Eragrostis cilianensis, Euphorbia thymifolia, Hemarthria compressa, Hybanthus \\
linearifolius, Leucas aspera, Leucas cephalotus, Lindernia ciliata*, Lindernia diffusa*, \\
Lobelia alsinoides, Martynia annua, Perotis indica, Rungia repens $*$ Senna pumila, \\
Spermacoce pusilla, Sphenoclea zeylanica, Teramnus labialis, Tribulus terrestris \\
Alternanthera pungens, Cajanus scarabaeoides, Heliotropium ovalifolium, Hygrophila \\
auriculata \\
Seed + Ramet \\
Seed + Rhizome + Storage roots \\
Seed + Sprout + Ramet & Heteropogon contortus, Imperata cylindrica $*$ Zephyranthes citrina \\
\hline
\end{tabular}


Table 9. Habitat specificity of rare plant species across the regional grassland vegetation of northeastern Uttar Pradesh. Light: O = Open, PS = Partial shade; Soil moisture: $\mathrm{HM}=$ High moisture, LM = Low moisture, AM = Average moisture; and Soil texture: $\mathrm{S}=$ Sandy, $\mathrm{G}=$ Gravel, $\mathrm{C}=$ Clay, $\mathrm{CL}=$ Clay-loam, $\mathrm{SL}=$ Sandy loam.

\begin{tabular}{|c|c|c|c|c|c|}
\hline \multirow{2}{*}{ No. } & \multirow{2}{*}{ Species } & \multirow{2}{*}{ Family } & \multicolumn{3}{|c|}{ Habitat specificity factors } \\
\hline & & & Light & Soil moisture & Soil texture \\
\hline 1 & Alternanthera pungens & Amaranthaceae & $\mathrm{O}$ & LM & $\mathrm{G}$ \\
\hline 2 & Alysicarpus bupleurifolius & Papilionaceae & $\mathrm{O}$ & $\mathrm{AM}$ & $\mathrm{C} / \mathrm{CL}$ \\
\hline 3 & Baccopa monnieri & Scrophulariaceae & $\mathrm{O}$ & HM & $\mathrm{C}$ \\
\hline 4 & Cajanus scarabaeoides & Papilionaceae & $\mathrm{O}$ & $\mathrm{AM}$ & $\mathrm{CL}$ \\
\hline 5 & Centella asiatica & Apiaceae & $\mathrm{O}$ & HM & $\mathrm{C}$ \\
\hline 6 & Chamaecrista absus & Caesalpiniaceae & PS & $\mathrm{AM}$ & $\mathrm{CL}$ \\
\hline 7 & Chrysanthellum indicum & Asteraceae & $\mathrm{O}$ & $\mathrm{AM}$ & S/SL \\
\hline 8 & Crotalaria calycina & Papilionaceae & $\mathrm{O}$ & LM & SL \\
\hline 9 & Crotalaria pallida & Papilionaceae & $\mathrm{O}$ & LM & SL \\
\hline 10 & Cullen corylifolium & Papilionaceae & PS & $\mathrm{AM}$ & SL \\
\hline 11 & Cynoglossum lanceolatum & Boraginaceae & $\mathrm{O}$ & LM & SL \\
\hline 12 & Cyperus niveus & Cyperaceae & $\mathrm{O}$ & $\mathrm{AM}$ & SL \\
\hline 13 & Eragrostis capensis & Poaceae & $\mathrm{O}$ & $\mathrm{AM}$ & $\mathrm{SL}$ \\
\hline 14 & Eragrostis cilianensis & Poaceae & $\mathrm{O}$ & $\mathrm{AM}$ & $\mathrm{C} / \mathrm{CL}$ \\
\hline 15 & Euphorbia thymifolia & Euphorbiaceae & $\mathrm{O}$ & LM & SL/G \\
\hline 16 & Evolvulus alsinoides & Convolvulaceae & $\mathrm{O}$ & $\mathrm{AM}$ & SL/S \\
\hline 17 & Heliotropium ovalifolium & Boraginaceae & $\mathrm{O}$ & $\mathrm{HM}$ & $\mathrm{C}$ \\
\hline 18 & Hemarthria compressa & Poaceae & $\mathrm{O}$ & HM & $\mathrm{C}$ \\
\hline 19 & Heteropogon contortus & Poaceae & $\mathrm{O}$ & $\mathrm{LM}$ & SL \\
\hline 20 & Hybanthus linearifolius & Violaceae & $\mathrm{O} / \mathrm{PS}$ & $\mathrm{AM}$ & SL/CL \\
\hline 21 & Hygrophila auriculata & Lamiaceae & $\mathrm{O}$ & $\mathrm{HM}$ & $\mathrm{C}$ \\
\hline 22 & Leucas aspera & Lamiaceae & $\mathrm{O}$ & LM & SL \\
\hline 23 & Leucas cephalotus & Lamiaceae & $\mathrm{O}$ & $\mathrm{AM}$ & SL \\
\hline 24 & Lobelia alsinoides & Lobeliaceae & PS & HM & CL \\
\hline 25 & Martynia аппиа & Martyniaceae & $\mathrm{O}$ & LM & $\mathrm{CL}$ \\
\hline 26 & Perotis indica & Poaceae & $\mathrm{O}$ & LM/AM & SL \\
\hline 27 & Senna pumila & Caesalpiniaceae & PS & $\mathrm{AM}$ & $\mathrm{CL}$ \\
\hline 28 & Spermacoce pusilla & Rubiaceae & $\mathrm{O}$ & $\mathrm{AM}$ & SL \\
\hline 29 & Sphenoclea zeylanica & Sphenocleaceae & $\mathrm{O}$ & HM & $\mathrm{C}$ \\
\hline 30 & Teramnus labialis & Papilionaceae & PS & $\mathrm{AM}$ & G \\
\hline 31 & Tribulus terrestris & Zygophyllaceae & $\mathrm{O}$ & LM & $\mathrm{S}$ \\
\hline 32 & Vernonia sp. & Asteraceae & $\mathrm{O}$ & $\mathrm{LM}$ & SL \\
\hline 33 & Zephyranthes citrina & Amaryllidaceae & $\mathrm{O} / \mathrm{PS}$ & $\mathrm{AM}$ & $\mathrm{G} \& \mathrm{C}$ \\
\hline
\end{tabular}

\section{Discussion}

\section{Community structure and diversity pattern}

This study shows that the Terai landscape contains very diverse assemblages and associations relative to semiarid grasslands in other parts of India (Pandeya 1964; Dabadghao and Shankaranarayan 1973), but owing to continued alteration of the habitats through anthropogenic disturbance, the resulting landscape is gradually losing a number of plant species, which can flourish only in a narrow habitat range. The very little similarity and drastic differences among grassland patches, in terms of species richness and abundance, are probably due to the severity of a range of factors, including clipping, grazing, trampling, habitat fragmentation, water-logging, mining and transportation of soil. Singh and Joshi (1979) considered that high numbers of associations in hygrophilous grasslands could be due to different intensities of anthropogenic disturbance plus local variations in topography and soil depth. Locations found on elevated mounds or 'dhus' supported a diverse assemblage of 
grasses and palatable herbs despite regular livestock grazing.

The grasslands in the study area showed much higher species richness than other vegetation types of the region, i.e. almost 3 times higher than that in adjacent forests (Pandey and Shukla 2003). Similar observations have been made in the protected grassland of Dudhwa National Park in Terai of Uttar Pradesh (Mathur et al. 2003). The reason for higher species diversity could be the variation in micro-habitat features and occurrence of a number of associations of grass species in the Terai grasslands (Shukla 2009).

Our analysis showed that annual herbs contributed most towards different phyto-sociological indices. While most herbaceous plant species can readily establish themselves, quickly produce herbage cover and improve soil fertility (Graham 1941), those which regenerate from seeds are less likely to persist in communities facing recurrent grazing and trampling, although forbs respond positively to disturbance (Belsky 1986). Prostrate perennial species, like Cynodon dactylon, Desmodium triflorum, Evolvulus nummularis and Rungia repens, showed marked dominance (density and IVI) across the region. They readily occupied the horizontal space created by disturbance through grazing and clipping, and often showed high seed production as well as ramet proliferation, even at sites facing regular disturbance. Multiple types of reproductive strategy can result in the dominance of species over an area (Harper and White 1974; Patrica et al. 2002). Moderate grazing also promotes rapid colonization of newly available space by these species, mainly through vegetative means.

The higher the abundance:frequency $(\mathrm{A}: \mathrm{F})$ ratio, the greater will be the tendency of species to clump, and vice-versa. Low values of both the abundance and frequency indicate rare occurrence of species, while very high values indicate dominance of species. A:F ratios of the most common prostrate perennial herbs like Desmodium triflorum and Evolvulus nummularis, were not high because both the abundance and frequency values of these species were quite high. The pattern of species abundance has been related to both growth pattern and habitat factors (Varghese and Menon 1999). Diversity is often considered to be a synthetic measure of a combination of structure, complexity and stability of a community (Hubbell and Foster 1983). Species distribution in a community is often non-random with dominant species being widely distributed, while subordinate species are generally locally distributed (Kolasa 1989). A moderate level of disturbance is, therefore, compatible with the maintenance of high biodiversity in the landscape. On the other hand, more severe disturbance through regular clipping causes greater dominance and low diversity, and the species of prostrate habit dominate the local communities (Gentry 1991).

The commonness between any two adjacent patches is proportional to the extent of their contact or boundary length (Cole and Hobbs 1994). Most of the adjacent patches of grassy landscape showed a number of common species, under genera like Lindernia, Phyllanthus, Oldenlandia and Heliotropium. The distribution of grassland species was largely random but several were also found locally aggregated on different spatial scales. A number of erect, prostrate and climber species showed aggregation in the form of compact to loose patches. Aggregation occurred due to either localized seed fall or vigorous vegetative proliferation through ramets. Pacala (1997) also reported that local or intra-specific aggregation is generated by limited seed dispersal, clonal growth and patchy environments.

The resource sharing and niche occupancy of species is frequently expressed by dominance-diversity curves (Whittaker 1975). Conditions like moderate grazing and reduced clipping and trampling allowed relatively greater numbers of species to share community resources, thus reducing the degree of dominance at the community level. A less steep and more flattened curve has also been reported by Raizada et al. (1998). However, some species depicted as rare by the curve, through quadrat sampling, were actually not so rare. They occurred in small patches but only on specified habitats with respect to soil moisture.

Disturbance may have positive effects on some species as reported earlier (Sundriyal et al. 1987) and that caused by herbivores may reduce the effect of competition (Grace and Jutila 1999). In comparison with other species in exposed communities, erect herbaceous species were dominant in terms of RD, RVC and IVI, especially in situations with low moisture and moderate disturbance. Lindernia diffusa occurred frequently and its dominance across the region may be due to frequent clipping and grazing. The periodic clipping inhibited the establishment of most of the upper strata species and promoted dominance of only a few prostrate species like Rungia repens and Desmodium triflorum.

\section{Commonness of plant species}

Forbs produce numerous fruits and seeds per plant. The seeds are usually small and often possess very hard seed coats, which can easily escape damage from trampling and digestion within the guts of birds, cattle and other animals. Evolvulus nummularis and Desmodium triflorum also regenerated efficiently through ramets and 
sprouts in addition to seeds. A few species like Mukia maderaspatana, Ranunculus scleratus, Ruellia tuberosa and Soliva anthemifolia were found in small loose patches with a good number of prostrate neighbors. Other species like Boerhavia diffusa and Clerodendrum indicum could directly build up a large phytomass from their root-stock and rhizome systems. Their dense vegetative cover suppresses the subordinate species and thus promotes the homogeneity of the community (Armesto and Pickett 1985).

Trampling had significant effects on the occurrence of some species. Croton bonplandianum, Parthenium hysterophorus and Acalypha indica were more common in areas facing frequent trampling, while species like Tridax procumbens, Cyanthillium cinereum, Alysicarpus monilifer and Murdannia nudiflora occurred when clipping and trampling were only occasional. With increased frequency of trampling and clipping, the occurrence of Achyranthes aspera, Amaranthus viridis, Ruellia tuberosa and Gomphrena globosa markedly increased. The combination of heavy trampling, grazing and clipping provided extreme conditions of biotic disturbance. Grasses, notably Setaria glauca, Eragrostis amabilis and Cyperus rotundus, and a few leguminous forbs, e.g. Desmodium triflorum and Alysicarpus monilifer, coped with such composite disturbance. About $10 \%$ of the common species showed ramet proliferation, while others displayed mass seed germination at suitable sites. Some prostrate species aggregated to form compact mats, which allowed few associates and low species richness of local communities. Erect species, on the other hand, allowed significant numbers of species among their aggregations. A number of new entrants produced propagules irrespective of their vitality level to the community. The dense vegetal cover of Hyptis suaveolens and Parthenium hysterophorus suppressed the growth of other species as evident at locality 8 (Marimata campus). Since these species were unpalatable and faced no clipping and little trampling owing to their height, they showed significant local dominance (Tripathi and Shukla 2007).

\section{Rarity of plant species}

A number of species, which showed low tolerance of disturbance and were totally absent from such sites (Table 6), occurred only in few localities and preferred sandy to loamy soils. Species such as Centella asiatica and Hygrophila auriculata, earlier frequent in or near water-logged areas, have also become quite rare during recent decades. On the other hand, a sizable number of species, which occupy quite specialized habitats, showed small population sizes within narrow distributional ranges (Table 6). Chiefly because of their medicinal importance, they have been over-exploited and are on the verge of local extinction. The population density of Chamaecrista absus, Cyperus niveus, Leucas cephalotus, Leucas aspera, Lobelia alsinoides, Martynia annua and Cullen corylifolium has declined markedly during the last few years. This indicates their specialized habitat requirements (Tripathi 1999). The land-use changes plus mining and transportation of soil for filling and construction purposes appear to be important threats. Voracious and unmanaged harvesting presents a major threat to the persistence of several valuable plant species of the region (Shukla 2009). Hubbell and Foster (1986) found that most rare species are specialists in terms of habitat or appropriate niches for regeneration. The fast expansion of townships and associated disturbances during the current era have caused major reduction in availability of specialized niches in the region.

The spread of viable seeds from parent plants can be restricted due to the absence of dispersal vectors, especially grazers. Several authors have highlighted the importance of migrating sheep and cattle for plant dispersal (Fischer et al. 1996; Poschlod et al. 1998). Although the fruits of Tribulus terrestris are dispersed far and wide through a hooking device, which attaches to the skin of cattle, the population of this species has shrunk rapidly during the last decade. A contributing factor could be the unavailability of suitable micro-sites for germination and growth of seeds. Crotalaria calycina and Hybanthus linearifolius are examples of species now classified as rare, as their population size has declined significantly during the last decade, despite production of sufficient viable seeds/fruits. These species prefer shaded and damp habitats around orchards, and availability of such habitats has declined markedly, mainly through increased urbanization and agricultural expansion. Metzger (2000) suggests that shade-tolerant species are more sensitive to habitat fragmentation than shadeintolerant species.

Species like Hygrophila auriculata, Bacopa monnieri, Centella asiatica and Heliotropium ovalifolium grow mostly on clayey soil subjected to some degree of water-logging. Currently, they have become infrequent across water-logged or lowland sites, despite their two-pronged regeneration strategy, i.e. through seeds as well as sprouts and ramets. With improvement of technologies and population explosion, humans have a major role in escalating extinction rates (Hopping et al. 2004). Species populations which are small in size and with restricted habitat requirements are more prone to extinction (Menges 1998; Butaye et al. 2005). 
It was quite striking that some very rare species in the regional grassland were the only representatives of a particular genus, which, in turn, represented a single family. For example, Lobeliaceae, Martyniaceae, Sphenocleaceae and Zygophyllaceae were represented by Lobelia alsinoides, Martynia annua, Sphenoclea zeylanica and Tribulus terrestris, respectively. The loss of these single species would mean the loss or non-representation of a whole family. These species may be passing through their lag time, as often there is a lag time between when the species habitat is lost and when the species actually becomes extinct (Hopping et al. 2004). A great amount of evolutionary history and biological distinctiveness is lost when the last species of an entire genus or family becomes extinct (Kareiva and Marvier 2003). Levin and Levin (2004) strongly suggest concentrating efforts on saving such families and higher levels of taxonomic groups.

The survival and growth of several plant species into large populations indicated that habitat quality was not always worse for all species, especially invaders, which form one of the major threats to the survival and growth of several native species (Sekar 2012). The invaders colonize and successfully out-compete the native species, especially in open habitats with reduced competition, often created by grazing and man-made disturbance ( $\mathrm{Wu}$ et al. 2004; Huang et al. 2009). The introduction and spread of invasive aliens may be facilitated by floods, changes in land-use pattern and environmental conditions caused by livestock grazing, timber harvest, agriculture and ornamental purposes (Srivastava et al. 2015). These alien species have the potential to damage or eliminate already feeble populations of rare taxa (Menges 1991).

\section{Conservation strategy of grasses}

Availability of viable seed is important for conservation of biodiversity and may determine the composition, structure and dynamics of present and future vegetation in different ecosystems. Grazing pressure in the Terai region is very intense and much of the seed-bearing parts of plants are removed. Further, developmental activities often create severe soil disturbance, and compaction and erosion have adverse impacts on the survival of grassland species (Godefroid and Koeda 2004a; 2004b). Disturbance complicates the relationship and may increase species richness by lowering dominance and presenting opportunities for some species to spread rapidly (Whitmore 1996; Gusson et al. 2009). The management of biodiversity at landscape levels involves the twin ob- jectives of preservation and sustainable use of natural habitats.

\section{Conclusion}

The present data on abundance distribution and diversity pattern of plant species suggest that the acute fragmentation of the natural habitat of northeastern Terai has resulted in limited distribution of once very common and widely spread species. Fast shrinkage of grassland habitats due to urbanization, agricultural expansion, grazing, trampling, fire and the mining and transportation of soil for the brick industry and site filling have pushed many less-common but valuable plant species towards rarity and several of them face local extinction. It appears that many valuable species will be lost from these grasslands, if the current practices in the community are allowed to continue unchecked. The present observations emphasize the urgent need for studies on the status of existing rare plant species and identification of the most detrimental cultural practices threatening their survival before some important species are lost from these plant communities.

\section{Acknowledgments}

The authors thank Jeremy Russell-Smith for his meticulous correction and thorough review and also to an anonymous reviewer for his critical comments. The Agriculture Research Centre, Bahraich, U.P. provided free facility to analyze soil samples. The authors are also thankful to the Head, Department of Botany, D.D.U. Gorakhpur University, Gorakhpur, India for providing access to the departmental herbarium and other required facilities.

\section{References}

Ansari AA; Singh SK; Srivastava RC. 2006. Flora and vegetation of Madhaulia forest (U.P.). Oriental Enterprises, Dehradun, Uttarakhand, India.

Armesto JJ; Pickett STA. 1985. Experiments on disturbance in old-field plant communities: Impact on species richness and abundance. Ecology 66:230-240. DOI: 10.2307/19 $\underline{41323}$

Belsky AJ. 1986. Revegetation of artificial disturbances in grasslands of the Serengeti National Park, Tanzania: II. Five years of successional change. Journal of Ecology 74:937-951. DOI: $10.2307 / 2260225$

Bharucha FR; Ferreria DB. 1941. The biological spectra of the Matheran and Mahabaleshwar flora. Journal of the Indian Botanical Society 20:195-211. 
Butaye J; Adriaens D; Honnay O. 2005. Conservation and restoration of calcareous grasslands: A concise review of the effects of fragmentation and management on plant species. Biotechnology, Agronomy, Society and Environment 9:111-118. http://goo.gl/vulcsa

Cole PG; Hobbs RJ. 1994. Landscape heterogeneity indices: Problems of scale and applicability, with particular reference to animal habitat description. Pacific Conservation Biology 1:183-193. DOI: 10.1071/PC940183

Dabadghao PM; Shankarnarayan KA. 1973. The grass cover of India. Indian Council of Agricultural Research, New Delhi, India.

Daniels RJ; Kumar AN; Jayanthi M. 1995. Endemic, rare and threatened flowering plants of South India. Current Science 68:493-495. http://goo.gl/1siFnz

Fischer SF; Poschlod P; Beinlich B. 1996. Experimental studies on the dispersal of plants and animals on sheep in calcareous grasslands. Journal of Applied Ecology 33:12061222. DOI: $\underline{10.2307 / 2404699}$

Friedel MH. 1997. Discontinuous change in arid woodland and grassland vegetation along gradients of cattle grazing in central Australia. Journal of Arid Environment 37:145164. DOI: $10.1006 /$ jare. 1997.0260

Gentry AH. 1991. The distribution and evolution of climbing plants. In: Putz FE; Mooney HA, eds. The biology of vines. Cambridge University Press, Cambridge, UK. p. 342.

Godefroid S; Koeda MN. 2004a. Interspecific variation in soil compaction sensitivity among forest floor species. Biological Conservation 119:207-217. DOI: 10.1016/j.biocon. 2003.11.009

Godefroid S; Koeda MN. 2004b. The impact of forest paths upon adjacent vegetation: Effects of the path surfacing material on the species composition and soil compaction. Biological Conservation 119:405-419. DOI: 10.1016/j.biocon. 2004.01.003

Grace JB; Jutila H. 1999. The relationship between species density and community biomass in grazed and ungrazed coastal meadows. Oikos 85:398-408. DOI: $\underline{10.2307 / 354}$ $\underline{6689}$

Graham EH. 1941. Legumes for erosion control and wildlife. USDA Miscellaneous Publication 412, US Department of Agriculture, Washington, DC, USA.

Grime JP. 1979. Plant strategies and vegetation processes. John Wiley \& Sons Ltd., Chichester, UK.

Gupta RK; Sharma SK. 1973. Phytosociological changes in an enclosed area of Jodhpur. Journal of the Indian Botanical Society 52:1-11.

Gusson AE; Lopes SF; Dias Neto OC; Vale VS do; Oliveira AP de; Schiavini I. 2009. Características químicas do solo e estrutura de um fragmento de floresta estacional semidecidual em Ipiaçu, Minas Gerais, Brasil. Rodriguésia 60:403-414. http://www.jstor.org/stable/23499997

Harper JL; White J. 1974. The demography of plants. Annual Review of Ecology and Systematics 5:419-463. DOI: $\underline{10.1146 / \text { annurev.es.05.110174.002223 }}$
Hopping I; Mackro D; Delson L. 2004. Human effects on terrestrial biodiversity. The Traprock 3:1-5.

Huang QQ; Wu JM; Bai YY; Zhou L; Wang GX. 2009. Identifying the most noxious invasive plants in China: Role of geographical origin, life form and means of introduction. Biodiversity and Conservation 18:305-316. DOI: 10.1007/ s10531-008-9485-2

Hubbell SP; Foster RB. 1983. Diversity of canopy trees in neo-tropical forest and implications to conservation. In: Sutton L; Whitmore TC; Chadwick C, eds. Tropical rain forest: Ecology and management. Blackwell Scientific Publications, Oxford, UK. p. 25-41.

Hubbell SP; Foster RB. 1986. Commonness and rarity in a neotropical rain forest: Implications for tropical tree conservation. In: Soulé ME, ed. Conservation Biology: The science of scarcity and diversity. Sinauer Associates, Sunderland, MA, USA. p. 205-231.

IUCN. 2001. IUCN Red List categories and criteria: Version 3.1. IUCN Species Survival Commission. International Union for Conservation of Nature, Gland, Switzerland and Cambridge, UK.

Kala CP. 2005. Indigenous uses, population density, and conservation of threatened medicinal plants in protected areas of the Indian Himalayas. Conservation Biology 19:368378. DOI: $10.1111 / \mathrm{j} .1523-1739.2005 .00602 . \mathrm{x}$

Kareiva P; Marvier M. 2003. Conserving biodiversity cold spots. American Scientist 91:344-351. DOI: 10.1511/2003. 4.344

Kolasa J. 1989. Ecological systems in hierarchical perspective: Breaks in community structure and other consequences. Ecology 70:36-47. DOI: 10.2307/1938410

Levin PS; Levin DA. 2004. The real biodiversity crisis. American Scientist 90:6-8. DOI: 10.1511/2002.1.6

Magurran AE. 1988. Ecological diversity and its measurement. University Press, Cambridge, UK.

Magurran AE. 2004. Measuring biological diversity. Blackwell Publishing, Oxford, UK.

Magurran AE; Henderson PA. 2003. Explaining the excess of rare species in natural species abundance distributions. Nature 422:714-716. DOI: 10.1038/nature01547

Mathur PK; Kumar H; Lehmkuhl JF. 2003. Terai grassland diversity, management and conservation perspectives. ENVIS Bulletin Grassland, Ecosystems and Agroforestry $1: 1-28$.

Menges ES. 1991. The application of minimum viable population theory to plants. In: Falk DA; Holsinger KE, eds. Genetics and conservation of rare plants. Oxford University Press, Oxford, UK. p. 47-61.

Menges ES. 1998. Evaluating extinction risks in plant populations. In: Fiedler PL; Kareiva PM, eds. Conservation biology for the coming decade. Chapman and Hall, New York, USA and London, UK. p. 49-65.

Metzger JP. 2000. Tree functional group richness and landscape structure in a Brazilian tropical fragmented landscape. Ecological Applications 10:1147-1161. DOI: 10. 18 90/1051-0761(2000)010\%5B1147:tfgral\%5D2.0.co;2 
Mori SA; Boom BM; Carvalino AM de; Santos TS dos. 1983. Ecological importance of Myrtaceae in an eastern Brazilian wet forest. Biotropica 15:68-70. DOI: 10.2307/2388002

Mueller-Dombois D; Ellenberg H. 1974. Aims and methods of vegetation ecology. John Wiley \& Sons Ltd., New York, USA.

Nautiyal BP; Pandey N; Bhatt AB. 1997. Analysis of vegetation pattern in an alpine zone in North West Himalaya: A case study of Garhwal Himalaya with reference to diversity and distribution patterns. International Journal of Ecology and Environmental Science 23:49-65.

Nayar MP; Sastry ARK, eds. 1988. Red data book of Indian plants. Botanical Survey of India, Calcutta, India.

Oostermeijer JGB; Luijten SH; den Nijs JCM. 2003. Integrating demographic and genetic approaches in plant conservation. Biological Conservation 113:389-398. DOI: $\underline{10.1016 /}$ s0006-3207(03)00127-7

Pacala SW. 1997. Dynamics of plant communities. In: Crawley MJ, ed. Plant ecology. Blackwell Scientific, Oxford, UK. p. 532-555.

Pandeya SC. 1964. Ecology of grassland of Sagar, Madhya Pradesh: IIb. Composition of the associations open to grazing or occupying special habitat. Journal of the Indian Botanical Society 43:606-639.

Pandey SK; Shukla RP. 2003. Plant diversity in managed sal (Shorea robusta Gaertn.) forests of Gorakhpur, India: Species composition, regeneration and conservation. Biodiversity and Conservation 12:2295-2319. DOI: 10.1023/ A: 1024589230554

Patrica B; Emily L; Gerardo S; Christina S; Angeles I. 2002. Patterns of $\beta$-diversity in a Mexican tropical dry forest. Journal of Vegetation Science 13:145-158. DOI: 10.1111/ j.1654-1103.2002.tb02034.x

Pickett STA; White PS, eds. 1985. The ecology of natural disturbance and patch dynamics. Academic Press, New York, USA.

Pitman NCA; Terborgh J; Silman MR; Nuñez PV. 1999. Tree species distributions in an upper Amazonian forest. Ecology 80:2651-2661. DOI: $10.1890 / 0012-9658(1999) \quad 080$ [2651:TSDIAU]2.0.CO;2

Poschlod P; Kiefer S; Tränke U; Fischer S; Bonn S. 1998. Plant species richness in calcareous grasslands as affected by dispersability in space and time. Applied Vegetation Science 1:75-91. DOI: $10.2307 / 1479087$

Rabinowitz D. 1981. Seven forms of rarity. In: Synge H, ed. The biological aspects of rare plant conservation. John Wiley \& Sons Ltd., New York, USA. p. 205-217.

Rabinowitz D; Cairns S; Dillon T. 1986. Seven forms of rarity and their frequency in the flora of the British Isles. In: Soule ME, ed. Conservation biology: The science of scarcity and diversity. Sinauer, Sunderland, MA, USA. p. 182204.

Raizada A; Joshi SP; Srivastava MM. 1998. Composition and vegetation diversity in an alpine grassland in the Garhwal Himalayas. Tropical Ecology 39:133-144.
Sekar KC. 2012. Invasive alien plants of Indian Himalayan region - diversity and implication. American Journal of Plant Sciences 3:177-184. DOI: 10.4236/ajps.2012.32021

Semwal RL. 2005. The Terai arc landscape in India: Securing protected areas in the face of global change. World Wide Fund for Nature (WWF)-India, New Delhi, India.

Shukla RP. 2009. Patterns of plant species diversity across Terai landscape in north-eastern Uttar Pradesh, India. Tropical Ecology 50:111-123.

Singh JS; Yadava PS. 1974. Seasonal variation in composition, plant biomass and net primary productivity of tropical grassland of Kurukshetra, India. Ecological Monographs 94:371-376. DOI: $10.2307 / 2937034$

Singh JS; Joshi MC. 1979. Primary production. In: Coupland RT, ed. Analysis of grassland and their uses. International Biological Programme (IBP) Synthesis Series, Cambridge University Press, London, UK.

Srivastava S; Dvivedi A; Shukla RP. 2014. Invasive alien species of terrestrial vegetation of north-eastern Uttar Pradesh. International Journal of Forestry Research Volume 2014, ID 959875, 9 pages. DOI: $10.1155 / 2014 / 959875$

Srivastava S; Dvivedi A; Shukla RP. 2015. Solanum sisymbriifolium Lam. (Solanaceae): A new invasive undershrub of the old-fields of northeastern Uttar Pradesh. Checklist: The Journal of Biodiversity Data. Volume 11, number 3, article 1643, 4 pages. DOI: $\underline{10.15560 / 11.3 .1643}$

Sundriyal RC; Joshi AP; Dhasmana R. 1987. Phenology of high altitude plants at Tungnath in the Garhwal Himalaya. Tropical Ecology 28:289-299.

Tripathi SL. 1999. Plant diversity of grasslands of northeastern U.P. with emphasis on populations of Parthenium hysterophorus L. Ph.D. Thesis. D.D.U. Gorakhpur University, Gorakhpur, India.

Tripathi SL; Shukla RP. 2007. Effect of clipping and grazing on various vegetational parameters of grassland communities of Gorakhpur, Uttar Pradesh. Tropical Ecology 48:6170 .

Ulrich W; Ollik M. 2004. Frequent and occasional species and the shape of relative-abundance distributions. Diversity and Distribution 10:263-269. DOI: 10.1111/j.1366-9516. 2004.00082.x

Varghese AO; Menon ARR. 1999. Ecological niches and amplitudes of rare threatened and endemic trees of Peppara Wildlife Sanctuary. Current Science 76:1204-1208.

Weekley CW; Race T. 2001. The breeding system of Zizyphus celata Judd \& D.W. Hall (Rhamnaceae), a rare, endemic plant of the Lake Wales Ridge, Florida, USA: Implications for recovery. Conservation Biology 100:207-213. DOI: 10.1016/S0006-3207\%2801\%2900024-6

Whitmore C. 1996. A review of some aspects of tropical rain forest seedling ecology with suggestions for further enquiry. In: Swaine MD, ed. The ecology of tropical forest seedlings. Man and the Biosphere Series Vol. 17, UNESCO, Paris, France and Parthenon Publishing Group, Inc. New York, USA. p. 3-39. 
Whittaker RH. 1975. Communities and Ecosystems. MacMillan Publishing Co., Inc., New York, USA.

Wilsey BJ; Polley HW. 2003. Effects of seed additions and grazing history on diversity and productivity of subhumid grasslands. Ecology 84:920-931. DOI: 10.1890/00129658(2003)084\%5B0920:eosaag\%5D2.0.co;2
Withford PB. 1948. Distribution of woodland plants in relation to succession and clonal growth. Ecology 30:199-208. DOI: $10.2307 / 1931186$

Wu SH; Hsieh CF; Rejmánek M. 2004. Catalogue of the naturalized flora of Taiwan. Taiwania 49:16-31. http://ntur.lib. ntu.edu.tw/retrieve/168216/05.pdf 


\section{Annex Ia}

Names and sampling areas of locations at the 11 study sites (districts). The habitat characteristics (see Annex Ib) at locations are expressed in terms of light regime (O - open, PS - partial shade); soil moisture (HM - high moisture, AM - average moisture, LM low moisture); soil texture (SS - sandy soil, LS - loam soil, CL - clay soil, SLS - sandy-loam soil, CLS - clay-loam soil and GS gravel soil); and disturbance regime (HD - high disturbance, MD - medium disturbance, LD - low disturbance).

\begin{tabular}{|c|c|c|c|}
\hline Study site & Location & Habitat characteristics & Area (ha) of sampling sites \\
\hline \multirow[t]{8}{*}{ Bahraich } & Acholaya (Stadium) & O,LM,SLS,LD & 10.12 \\
\hline & Acholaya I & O,AM,SLS,MD & 10.12 \\
\hline & Acholaya II & PS,HM,SLS,HD & 11.33 \\
\hline & Acholaya III & O,LM,SLS,HD & 14.17 \\
\hline & Acholaya Dhus & O,AM,SLS,MD & 4.05 \\
\hline & Basahiya & O,LM,SS,MD & 9.71 \\
\hline & Tikora (Parag Dairy) & $\mathrm{O}, \mathrm{HM}, \mathrm{HD}, \mathrm{CS}$ & 36.42 \\
\hline & Tikora (Mari Mata) & PS,AM,CLS,MD & 2.02 \\
\hline \multirow[t]{4}{*}{ Balrampur } & Neel Palace & PS,AM,GS,LD & 1.21 \\
\hline & Ranjeetpur & O,HM,CS,HD & 8.09 \\
\hline & Hanuman Mandir & $\mathrm{O}, \mathrm{HM}, \mathrm{CS}, \mathrm{LD}$ & 2.83 \\
\hline & Rani Talab & O,LM,CLS,MD & 1.21 \\
\hline Gonda & Sarayya Mafi & O,LM,LS,HD & 80.94 \\
\hline Shravasti & Mahaet & O,LM,GS,LD & 12.14 \\
\hline Basti & Ramauli & PS,AM,CLS,MD & 3.24 \\
\hline Sant Kabir Nagar & Maghar & O,HM,CS,HD & 11.33 \\
\hline Siddharth Nagar & Piperahawa & $\mathrm{O}, \mathrm{AM}, \mathrm{CS}, \mathrm{MD}$ & 38.45 \\
\hline \multirow[t]{2}{*}{ Maharajganj } & Chhapwa I & $\mathrm{O}, \mathrm{AM}, \mathrm{CLS}, \mathrm{MD}$ & 2.43 \\
\hline & Chhapwa II & PS,LM,SLS,LD & 2.05 \\
\hline \multirow[t]{5}{*}{ Gorakhpur } & University Campus & O,AM,CLS,MD & 6.07 \\
\hline & Airforce I & PS,AM,CLS,HD & 7.29 \\
\hline & Airforce II & O,LM,CLS,MD & 7.29 \\
\hline & Airforce III & PS,HM,CLS,HD & 8.09 \\
\hline & Jagatbella & O,HM,CS,MD & 12.14 \\
\hline \multirow[t]{3}{*}{ Kushi Nagar } & Sirshya I & O,LM,SLS,LD & 4.86 \\
\hline & Sirshya II & O,LM,SLS,MD & 2.43 \\
\hline & Sirshya III & PS,AM,SLS,HD & 2.02 \\
\hline \multirow[t]{4}{*}{ Deoria } & Deoghat I & PS,LM,SLS,MD & 6.07 \\
\hline & Deoghat II & PS,AM,SLS,HD & 2.02 \\
\hline & Uska & PS,HM,CLS,MD & 5.67 \\
\hline & Singahi & PS,HM,CLS,HD & 5.20 \\
\hline
\end{tabular}




\section{Annex Ib}

\section{Habitat identification}

The habitats of plant species were determined on the basis of characteristics that increase the heterogeneity of terrestrial vegetation: change in local topography; light regime; soil moisture; soil texture; and degree and type of anthropogenic disturbances.

Light regime: The degree of exposure was measured by an illuminometer (Kyoritsu-5200) at 10 random and nearly equidistant points on the floor of the vegetation during sunny days of November at mid-day. The light regime of open communities ranged from 70,000 to 75,000 lux and that of partially shaded communities was below 10,000 lux.

Soil moisture regime: The moisture content within the top 10 $\mathrm{cm}$ of soil was measured gravimetrically. More than $40 \%$ of soil moisture was treated as high moisture (HM), $20-40 \%$ as average moisture (AM) and $<20 \%$ as low moisture (LM).

Soil texture: Soil texture refers to particle size composition and according to the proportions of sand, silt and clay, soils are classified, in general, as sandy, clayey, loamy, sandy-loam, silty-loam, clayey-loam and silty-clay soils. The physical characterization of soil at the study sites is based on analysis by the Agricultural Research Center, Bahraich (U.P.), India (Table A below). The silty-loam and silty-clay soils were termed as gravelly soil as they contained significant proportions of gravels and pebbles.

Disturbance: The anthropogenic disturbance factors (see also Table B below) operating at each sampling location were recorded. The intensity of each factor was scaled in the classes: 1 (absent or very little); 2 (occasional); and 3 (recurrent) (see Table $\mathrm{C}$ below).

Table A. Soil physical characteristics at the study locations within 11 districts across grassy landscapes of northeastern Uttar Pradesh.

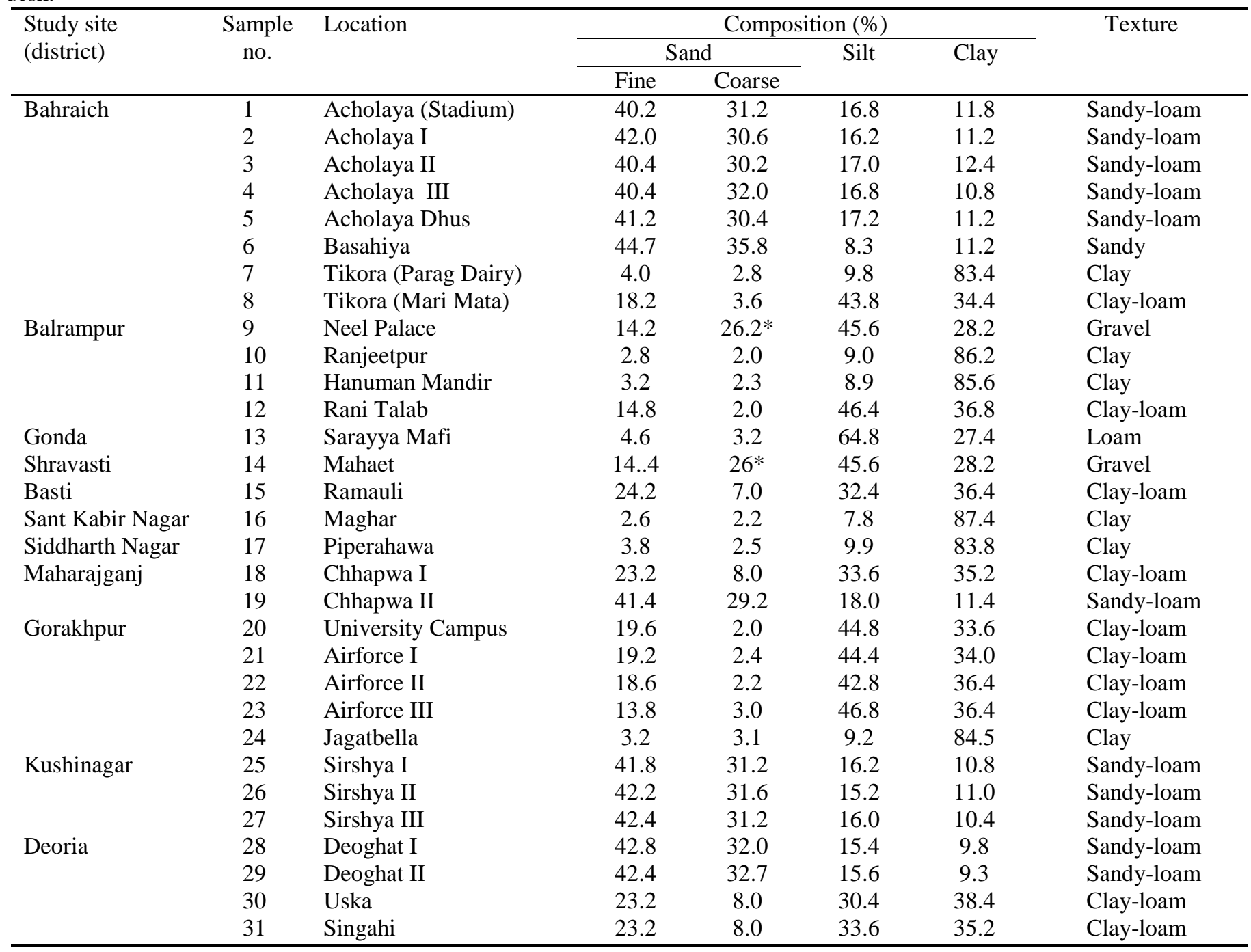

*The coarse sand fraction also included gravels and pebbles. 
Table B. Different types of disturbance classes at the study sites and their weightage score across grassy landscapes of northeastern Uttar Pradesh.

\begin{tabular}{lccc}
\hline Disturbance factor & Very little & Occasional & Recurrent \\
\hline Agricultural practices & 1 & 2 & 3 \\
Fire & 1 & 2 & 3 \\
Forage removal & 1 & 2 & 3 \\
Fuel wood collection & 1 & 2 & 3 \\
Grazing & 1 & 2 & 3 \\
Habitat destruction & 1 & 2 & 3 \\
Horticulture & 1 & 2 & 3 \\
Invasion & 1 & 2 & 3 \\
Litter collection & 1 & 2 & 3 \\
Mining of soil & 1 & 2 & 3 \\
Root collection & 1 & 2 & 3 \\
Trampling & 1 & 2 & 3 \\
Flood & 1 & 2 & 3 \\
\hline
\end{tabular}

Table C. Disturbance levels based on weightage scores of various disturbances.

\begin{tabular}{ll}
\hline Disturbance level & Weightage score \\
\hline Low & 1 or 2 or 3 \\
Medium & 1 and 2 or 1 and 3 \\
High & 1 and 2 and 3 \\
\hline
\end{tabular}




\section{Annex II}

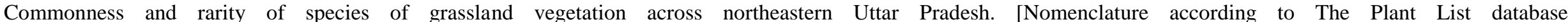

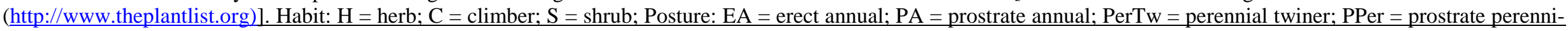
$\underline{\mathrm{al} ; \mathrm{ATw}=\text { annual twiner; EPer }=\text { erect perennial; } \mathrm{ATn}=\text { annual tendril. }}$

\begin{tabular}{|c|c|c|c|c|c|c|c|c|}
\hline Plant species & Family & Habit & Posture & $\begin{array}{l}\text { Total no. } \\
\text { individuals }\end{array}$ & $\begin{array}{c}\text { Density } \\
\left(/ \mathrm{m}^{2}\right)\end{array}$ & $\begin{array}{l}\text { Population } \\
\text { size }\end{array}$ & $\begin{array}{c}\text { Habitat } \\
\text { specialization }\end{array}$ & $\begin{array}{c}\text { Geographical } \\
\text { range }\end{array}$ \\
\hline Acalypha ciliata Forssk. & Euphorbiaceae & $\mathrm{H}$ & EA & 10 & 0.07 & Large & Broad & Wide \\
\hline Acalypha indica $\mathrm{L}$. & Euphorbiaceae & $\mathrm{H}$ & EA & 6 & 0.04 & Large & Broad & Wide \\
\hline Achyranthes aspera L. & Amaranthaceae & $\mathrm{H}$ & EA & 63 & 0.41 & Large & Broad & Wide \\
\hline Aerva lanata (L.) Juss. & Amaranthaceae & $\mathrm{H}$ & EA & 34 & 0.30 & Small & Broad & Wide \\
\hline Aeschynomene aspera L. & Papilionaceae & $\mathrm{H}$ & EA & 7 & 0.05 & Large & Broad & Wide \\
\hline Aeschynomene indica L. & Papilionaceae & $\mathrm{H}$ & EA & 3 & 0.02 & Large & Broad & Wide \\
\hline Ageratum conyzoides (L.) L. & Asteraceae & $\mathrm{H}$ & EA & 32 & 0.21 & Large & Broad & Wide \\
\hline Ageratum houstonianum Mill. & Asteraceae & $\mathrm{H}$ & EA & 357 & 2.30 & Large & Broad & Wide \\
\hline Alternanthera paronychioides A.St.-Hil. & Amaranthaceae & $\mathrm{H}$ & PA & 148 & 0.95 & Large & Broad & Wide \\
\hline Alternanthera pungens Kunth & Amaranthaceae & $\mathrm{H}$ & PA & 9 & 0.06 & Large & Narrow & Narrow \\
\hline Alternanthera sessilis (L.) R.Br. ex DC. & Amaranthaceae & $\mathrm{H}$ & PA & 187 & 1.21 & Large & Broad & Wide \\
\hline Alysicarpus bupleurifolius (L.) DC. & Papilionaceae & $\mathrm{H}$ & EA & 33 & 0.21 & Large & Narrow & Narrow \\
\hline Alysicarpus longifolius (Spreng.) Wight \& Arn. & Papilionaceae & $\mathrm{H}$ & EA & 14 & 0.09 & Small & Broad & Wide \\
\hline Alysicarpus monilifer (L.) DC. & Papilionaceae & $\mathrm{H}$ & PA & 324 & 2.09 & Large & Broad & Wide \\
\hline Alysicarpus ovalifolius (Schum.) Leonard & Papilionaceae & $\mathrm{H}$ & EA & 26 & 0.17 & Small & Broad & Wide \\
\hline Alysicarpus vaginalis (L.) DC. & Papilionaceae & $\mathrm{H}$ & PA & 667 & 4.30 & Large & Broad & Wide \\
\hline Amaranthus spinosus L. & Amaranthaceae & $\mathrm{H}$ & EA & 1 & 0.01 & Large & Broad & Wide \\
\hline Amaranthus viridis L. & Amaranthaceae & $\mathrm{H}$ & EA & 57 & 0.37 & Large & Broad & Wide \\
\hline Ammannia auriculata Willd. & Lythraceae & $\mathrm{H}$ & EA & 48 & 0.41 & Small & Broad & Wide \\
\hline Ammannia baccifera L. & Lythraceae & $\mathrm{H}$ & EA & 72 & 0.46 & Small & Broad & Wide \\
\hline Anagallis arvensis $\mathrm{L}$. & Primulaceae & $\mathrm{H}$ & EA & 71 & 0.46 & Large & Broad & Wide \\
\hline Apluda mutica $\mathrm{L}$. & Poaceae & $\mathrm{H}$ & EA & 46 & 0.30 & Small & Broad & Wide \\
\hline Argemone mexicana $\mathrm{L}$. & Papaveraceae & $\mathrm{H}$ & EA & 7 & 0.05 & Large & Broad & Wide \\
\hline Bacopa monnieri (L.) Wettst. & Scrophulariaceae & $\mathrm{H}$ & EA & 8 & 0.05 & Small & Narrow & Narrow \\
\hline Basella alba $\mathrm{L}$ & Basellaceae & $\mathrm{C}$ & PerTw & 3 & 0.02 & Small & Broad & Wide \\
\hline Blumea axillaris (Lam.) DC. & Asteraceae & $\mathrm{H}$ & EA & 8 & 0.05 & Large & Broad & Wide \\
\hline Blumea eriantha DC. & Asteraceae & $\mathrm{H}$ & EA & 35 & 0.23 & Large & Broad & Wide \\
\hline Blumea lacera (Burm.f.) DC. & Asteraceae & $\mathrm{H}$ & EA & 8 & 0.05 & Small & Broad & Wide \\
\hline Blumea laciniata (Wall. ex Roxb.) DC. & Asteraceae & $\mathrm{H}$ & EA & 26 & 0.17 & Small & Broad & Wide \\
\hline Boerhavia diffusa $\mathrm{L}$ & Nyctaginaceae & $\mathrm{H}$ & PPer & 120 & 0.77 & Large & Broad & Wide \\
\hline Bolboschoenus glaucus (Lam.) S.G.Sm. & Cyperaceae & $\mathrm{H}$ & EA & 23 & 0.15 & Small & Broad & Wide \\
\hline Cajanus scarabaeoides (L.) Thouars & Papilionaceae & $\mathrm{C}$ & ATw & 27 & 0.17 & Small & Narrow & Narrow \\
\hline Calotropis procera (Aiton) Druand. & Asclepiadaceae & $\mathrm{S}$ & EPer & 36 & 0.23 & Large & Broad & Wide \\
\hline Cannabis sativa $\mathrm{L}$. & Cannabinaceae & $\mathrm{H}$ & EA & 1 & 0.01 & Large & Broad & Wide \\
\hline
\end{tabular}




\begin{tabular}{|c|c|c|c|c|c|c|c|c|}
\hline Plant species & Family & Habit & Posture & $\begin{array}{l}\text { Total no. } \\
\text { individuals }\end{array}$ & $\begin{array}{c}\text { Density } \\
\left(/ \mathrm{m}^{2}\right)\end{array}$ & $\begin{array}{c}\text { Population } \\
\text { size }\end{array}$ & $\begin{array}{c}\text { Habitat } \\
\text { specialization }\end{array}$ & $\begin{array}{c}\text { Geographical } \\
\text { range }\end{array}$ \\
\hline Carex fedia Nees & Cyperaceae & $\mathrm{H}$ & EA & 186 & 1.20 & Large & Broad & Wide \\
\hline Cayratia trifolia (L.) Domin & Vitaceae & $\mathrm{C}$ & ATn & 16 & 0.10 & Large & Broad & Wide \\
\hline Ceesulia axillaris Roxb. & Asteraceae & $\mathrm{H}$ & EA & 143 & 0.92 & Large & Broad & Wide \\
\hline Cenchrus biflorus Roxb. & Poaceae & $\mathrm{H}$ & EA & 11 & 0.07 & Large & Broad & Wide \\
\hline Centella asiatica $(\mathrm{L}$.$) Urb.$ & Apiaceae & $\mathrm{H}$ & PA & 17 & 0.11 & large & Narrow & Wide \\
\hline Chamaecrista absus (L.) H.S.Irwin \& Barneby & Caesalpiniaceae & $\mathrm{H}$ & EA & 7 & 0.05 & Small & Narrow & Narrow \\
\hline Chenopodium album $\mathrm{L}$. & Chenopodiaceae & $\mathrm{H}$ & EA & 24 & 0.15 & Large & Broad & Wide \\
\hline Chloris barbata $\mathrm{Sw}$. & Poaceae & $\mathrm{H}$ & EA & 467 & 3.01 & Small & Broad & Wide \\
\hline Chrysanthellum indicum DC. & Asteraceae & $\mathrm{H}$ & PA & 595 & 3.84 & Large & Narrow & Narrow \\
\hline Chrysopogon aciculatus (Retz.) Trin. & Poaceae & $\mathrm{H}$ & EA & 790 & 5.10 & Large & Broad & Wide \\
\hline Cissampelos pareira $\mathrm{L}$. & Menispermaceae & $\mathrm{C}$ & PerTw & 8 & 0.05 & Small & Broad & Wide \\
\hline Cleome viscosa $\mathrm{L}$. & Capparidaceae & $\mathrm{H}$ & EA & 7 & 0.05 & Large & Broad & Wide \\
\hline Clerodendrum indicum (L.) Kuntze & Verbenaceae & $\mathrm{S}$ & EPer & 55 & 0.35 & Small & Broad & Wide \\
\hline Coccinia grandis (L.) Voigt & Cucurbitaceae & $\mathrm{C}$ & ATn & 9 & 0.06 & Large & Broad & Wide \\
\hline Commelina benghalensis L. & Commelinaceae & $\mathrm{H}$ & PA & 27 & 0.17 & Large & Broad & Wide \\
\hline Commelina diffusa Burm.f. & Commelinaceae & $\mathrm{H}$ & PA & 45 & 0.29 & Small & Broad & Wide \\
\hline Corchorus aestuans L. & Tiliaceae & $\mathrm{H}$ & PA & 83 & 0.54 & Large & Broad & Wide \\
\hline Corchorus fascicularis Lam. & Tiliaceae & $\mathrm{H}$ & EA & 57 & 0.37 & Large & Broad & Wide \\
\hline Crotalaria calycina Schrank & Papilionaceae & $\mathrm{H}$ & EA & 15 & 0.10 & Large & Narrow & Narrow \\
\hline Crotalaria medicaginea Lam. & Papilionaceae & $\mathrm{H}$ & EA & 123 & 0.79 & Large & Broad & Wide \\
\hline Crotalaria pallida Aiton & Papilionaceae & $\mathrm{H}$ & PA & 1 & 0.01 & Small & Broad & Wide \\
\hline Crotalaria prostrata Willd. & Papilionaceae & $\mathrm{H}$ & EA & 512 & 3.30 & Large & Narrow & Narrow \\
\hline Crotalaria retusa $\mathrm{L}$. & Papilionaceae & $\mathrm{H}$ & PA & 1 & 0.01 & Small & Broad & Wide \\
\hline Crotalaria sp. & Papilionaceae & $\mathrm{H}$ & PA & 79 & 0.51 & Small & Broad & Wide \\
\hline Croton bonplandianus Baill. & Euphorbiaceae & $\mathrm{H}$ & EA & 69 & 0.45 & Large & Broad & Wide \\
\hline Cucumis melo $\mathrm{L}$. & Cucurbitaceae & $\mathrm{C}$ & ATn & 9 & 0.06 & Large & Broad & Wide \\
\hline Cullen corylifolium (L.) Medik. & Papilionaceae & $\mathrm{H}$ & EA & 191 & 1.23 & Small & Narrow & Narrow \\
\hline Cuscuta chinensis Lam. & Cuscutaceae & $\mathrm{C}$ & ATw & 1 & 0.01 & Large & Broad & Wide \\
\hline Cuscuta sp. & Cuscutaceae & $\mathrm{C}$ & ATw & 50 & 0.32 & Large & Broad & Wide \\
\hline Cyanotis axillaris (L.) D.Don ex Sweet & Commelinaceae & $\mathrm{H}$ & EA & 137 & 0.88 & Small & Broad & Wide \\
\hline Cyanthillium cinereum (L.) H.Rob. & Asteraceae & $\mathrm{H}$ & EA & 1,077 & 6.95 & Large & Broad & Wide \\
\hline Cynodon dactylon (L.) Pers. & Poaceae & $\mathrm{H}$ & PPer & 3,644 & 23.51 & Large & Broad & Wide \\
\hline Cynoglossum lanceolatum Forssk. & Boraginaceae & $\mathrm{H}$ & EA & 123 & 0.79 & Large & Narrow & Narrow \\
\hline Cyperus alopecuroides Rottb. & Cyperaceae & $\mathrm{H}$ & EA & 262 & 1.69 & Large & Broad & Wide \\
\hline Cyperus alulatus J.Kern & Cyperaceae & $\mathrm{H}$ & EA & 47 & 0.30 & Small & Broad & Wide \\
\hline Cyperus capitatus Vand. & Cyperaceae & $\mathrm{H}$ & EA & 568 & 3.66 & Large & Broad & Wide \\
\hline Cyperus castaneus Willd. & Cyperaceae & $\mathrm{H}$ & EA & 130 & 0.84 & Small & Broad & Wide \\
\hline Cyperus compressus L. & Cyperaceae & $\mathrm{H}$ & EA & 31 & 0.20 & Large & Broad & Wide \\
\hline Cyperus difformis $\mathrm{L}$. & Cyperaceae & $\mathrm{H}$ & EA & 51 & 0.33 & Small & Broad & Wide \\
\hline
\end{tabular}




\begin{tabular}{|c|c|c|c|c|c|c|c|c|}
\hline Plant species & Family & Habit & Posture & $\begin{array}{c}\text { Total no. } \\
\text { individuals }\end{array}$ & $\begin{array}{c}\text { Density } \\
\left(/ \mathrm{m}^{2}\right)\end{array}$ & $\begin{array}{l}\text { Population } \\
\text { size }\end{array}$ & $\begin{array}{c}\text { Habitat } \\
\text { specialization }\end{array}$ & $\begin{array}{l}\text { Geographical } \\
\text { range }\end{array}$ \\
\hline Cyperus dubius Rottb. & Cyperaceae & $\mathrm{H}$ & EA & 150 & 0.97 & Large & Broad & Wide \\
\hline Cyperus exaltatus Retz. & Cyperaceae & $\mathrm{H}$ & EA & 13 & 0.08 & Small & Broad & Wide \\
\hline Cyperus michelianus (L.) Delile & Cyperaceae & $\mathrm{H}$ & PA & 13 & 0.08 & Large & Broad & Wide \\
\hline Cyperus niveus Retz. & Cyperaceae & $\mathrm{H}$ & EA & 2 & 0.01 & Small & Narrow & Narrow \\
\hline Cyperus rotundus $\mathrm{L}$. & Cyperaceae & $\mathrm{H}$ & EA & 44 & 0.28 & Large & Broad & Wide \\
\hline Cyperus sp. 1 & Cyperaceae & $\mathrm{H}$ & EA & 68 & 0.44 & Large & Broad & Wide \\
\hline Cyperus sp. 2 & Cyperaceae & $\mathrm{H}$ & EA & 269 & 1.74 & Small & Broad & Wide \\
\hline Cyperus sp. 3 & Cyperaceae & $\mathrm{H}$ & EA & 74 & 0.48 & Large & Broad & Wide \\
\hline Cyperus sp. 4 & Cyperaceae & $\mathrm{H}$ & EA & 28 & 0.18 & Small & Broad & Wide \\
\hline Cyperus trachysanthos Hook. \& Arn. & Cyperaceae & $\mathrm{H}$ & EA & 353 & 2.28 & Large & Broad & Wide \\
\hline Dactyloctenium aegyptium (L.) Willd. & Poaceae & $\mathrm{H}$ & EA & 622 & 4.01 & Large & Broad & Wide \\
\hline Dentella repens (L.) R.Forst. \& G.Forst. & Rubiaceae & $\mathrm{H}$ & PA & 251 & 1.62 & Small & Broad & Wide \\
\hline Desmodium gangeticum (L.) DC. & Papilionaceae & $\mathrm{H}$ & EPer & 52 & 0.34 & Large & Broad & Wide \\
\hline Desmodium triflorum (L.) DC. & Papilionaceae & $\mathrm{H}$ & PPer & 9,015 & 58.16 & Large & Broad & Wide \\
\hline Desmostachya bipinnata (L.) Stapf & Poaceae & $\mathrm{H}$ & EPer & 140 & 0.90 & Large & Broad & Wide \\
\hline Dichanthium annulatum (Forssk.) Stapf & Poaceae & $\mathrm{H}$ & EA & 1,028 & 6.63 & Large & Broad & Wide \\
\hline Digera muricata (L.) Mart. & Amaranthaceae & $\mathrm{H}$ & EA & 3 & 0.02 & Small & Broad & Wide \\
\hline Digitaria ciliaris (Retz.) Koeler & Poaceae & $\mathrm{H}$ & EA & 218 & 1.41 & Small & Broad & Wide \\
\hline Echinochloa colona (L.) Link & Poaceae & $\mathrm{H}$ & EA & 65 & 0.42 & Large & Broad & Wide \\
\hline Eclipta prostrata (L.) L. & Asteraceae & $\mathrm{H}$ & EA & 49 & 0.32 & Large & Broad & Wide \\
\hline Elephantopus scaber L. & Asteraceae & $\mathrm{H}$ & PA & 132 & 0.85 & Large & Broad & Wide \\
\hline Emilia sonchifolia (L.) DC. ex DC. & Asteraceae & $\mathrm{H}$ & EA & 273 & 1.76 & Small & Broad & Wide \\
\hline Eragrostis amabilis (L.) Wight \& Arn. & Poaceae & $\mathrm{H}$ & EA & 2,330 & 15.03 & Large & Broad & Wide \\
\hline Eragrostis capensis (Thunb.) Trin. & Poaceae & $\mathrm{H}$ & EA & 45 & 0.29 & Small & Narrow & Narrow \\
\hline Eragrostis cilianensis (All.) Janch. & Poaceae & $\mathrm{H}$ & EA & 29 & 0.19 & Small & Narrow & Narrow \\
\hline Eragrostis minor Host & Poaceae & $\mathrm{H}$ & EA & 420 & 2.71 & Large & Broad & Wide \\
\hline Eragrostis pilosa (L.) P.Beauv. & Poaceae & $\mathrm{H}$ & EA & 92 & 0.59 & Small & Broad & Wide \\
\hline Eragrostis unioloides (Retz.) Nees ex Steud. & Poaceae & $\mathrm{H}$ & EA & 969 & 6.25 & Large & Broad & Wide \\
\hline Erigeron bonariensis L. & Asteraceae & $\mathrm{H}$ & EA & 12 & 0.08 & Large & Broad & Wide \\
\hline Euphorbia hirta L. & Euphorbiaceae & $\mathrm{H}$ & EA & 54 & 0.35 & Large & Broad & Wide \\
\hline Euphorbia hypericifolia $\mathrm{L}$. & Euphorbiaceae & $\mathrm{H}$ & EA & 54 & 0.35 & Large & Broad & Wide \\
\hline Euphorbia thymifolia L. & Euphorbiaceae & $\mathrm{H}$ & PA & 29 & 0.19 & Small & Narrow & Wide \\
\hline Evolvulus alsinoides (L.) L. & Convolvulaceae & $\mathrm{H}$ & PPer & 763 & 4.92 & large & Narrow & Wide \\
\hline Evolvulus nummularius (L.) L. & Convolvulaceae & $\mathrm{H}$ & PPer & 7,805 & 50.36 & Large & Broad & Wide \\
\hline Ficus heterophylla L.f. & Moraceae & $\mathrm{S}$ & EPer & 5 & 0.03 & Large & Broad & Wide \\
\hline Fimbristylis aestivalis Vahl & Cyperaceae & $\mathrm{H}$ & EA & 144 & 0.93 & Large & Broad & Wide \\
\hline Fimbristylis bisumbellata (Forssk.) Bubani & Cyperaceae & $\mathrm{H}$ & EA & 2,406 & 15.52 & Large & Broad & Wide \\
\hline Fimbristylis cymosa $\mathrm{R} . \mathrm{Br}$. & Cyperaceae & $\mathrm{H}$ & EA & 228 & 1.47 & Small & Broad & Wide \\
\hline Fimbristylis dichotoma (L.) Vahl & Cyperaceae & $\mathrm{H}$ & EA & 3 & 0.02 & Small & Broad & Wide \\
\hline
\end{tabular}




\begin{tabular}{|c|c|c|c|c|c|c|c|c|}
\hline Plant species & Family & Habit & Posture & $\begin{array}{c}\text { Total no. } \\
\text { individuals }\end{array}$ & $\begin{array}{c}\text { Density } \\
\left(/ \mathrm{m}^{2}\right)\end{array}$ & $\begin{array}{l}\text { Population } \\
\text { size }\end{array}$ & $\begin{array}{c}\text { Habitat } \\
\text { specialization }\end{array}$ & $\begin{array}{l}\text { Geographical } \\
\text { range }\end{array}$ \\
\hline $\begin{array}{l}\text { Fimbristylis falcata (Vahl) Kunth } \\
\text { (V) }\end{array}$ & Cyperaceae & $\mathrm{H}$ & EA & 406 & 2.62 & Small & Broad & Wide \\
\hline Fimbristylis ovata (Burm.f.) J.Kern & Cyperaceae & $\mathrm{H}$ & EA & 1,187 & 7.66 & Large & Broad & Wide \\
\hline Fimbristylis quinquangularis (Vahl) Kunth & Cyperaceae & $\mathrm{H}$ & EA & 608 & 3.92 & Large & Broad & Wide \\
\hline Fimbristylis schoenoides (Retz.) Vahl & Cyperaceae & $\mathrm{H}$ & EA & 367 & 2.37 & Large & Broad & Wide \\
\hline Fimbristylis sp. & Cyperaceae & $\mathrm{H}$ & EA & 60 & 0.39 & Small & Broad & Wide \\
\hline Fumaria indica (Hausskn.) Pugsley & Fumariaceae & $\mathrm{H}$ & EA & 1 & 0.01 & Large & Broad & Wide \\
\hline Glinus lotoides L. & Molluginaceae & $\mathrm{H}$ & PA & 16 & 0.10 & Small & Broad & Wide \\
\hline Glinus oppositifolius (L.) Aug.DC. & Molluginaceae & $\mathrm{H}$ & PA & 37 & 0.24 & Small & Broad & Wide \\
\hline Gnaphalium polycaulon Pers. & Asteraceae & $\mathrm{H}$ & EA & 142 & 0.95 & Small & Broad & Wide \\
\hline Gomphrena celosioides Mart. & Amaranthaceae & $\mathrm{H}$ & EA & 40 & 0.26 & Large & Broad & Wide \\
\hline Grangea maderaspatana (L.) Poir. & Asteraceae & $\mathrm{H}$ & PA & 72 & 0.46 & Large & Broad & Wide \\
\hline Heliotropium indicum $\mathrm{L}$. & Boraginaceae & $\mathrm{H}$ & EA & 13 & 0.08 & Small & Broad & Wide \\
\hline Heliotropium ovalifolium Forssk. & Boraginaceae & $\mathrm{H}$ & EA & 12 & 0.08 & Small & Narrow & Narrow \\
\hline Heliotropium strigosum Willd. & Boraginaceae & $\mathrm{H}$ & PPer & 2,917 & 18.82 & Small & Broad & Wide \\
\hline Hemarthria compressa (L.f.) R.Br. & Poaceae & $\mathrm{H}$ & EA & 47 & 0.30 & Large & Narrow & Narrow \\
\hline Hemidesmus indicus (L.) R.Br. ex Schult. & Asclepiadaceae & $\mathrm{C}$ & PerTw & 51 & 0.33 & Small & Broad & Wide \\
\hline Hemigraphis hirta (Vahl) T.Anderson & Acanthaceae & $\mathrm{H}$ & PA & 229 & 1.48 & Large & Broad & Wide \\
\hline Heteropogon contortus (L.) P.Beauv. ex Roem. \& Schult. & Poaceae & $\mathrm{H}$ & EPer & 25 & 0.16 & Large & Narrow & Narrow \\
\hline Hybanthus linearifolius (Vahl) Urb. & Violaceae & $\mathrm{H}$ & EA & 122 & 0.79 & Small & Narrow & Wide \\
\hline Hygrophila auriculata (Schumach.) Heine & Lamiaceae & $\mathrm{H}$ & EA & 13 & 0.08 & Large & Broad & Narrow \\
\hline Hygrophila difformis Blume & Acanthaceae & $\mathrm{H}$ & EA & 12 & 0.08 & Small & Broad & Wide \\
\hline Hyptis suaveolens (L.) Poit. & Lamiaceae & $\mathrm{H}$ & EA & 186 & 1.20 & Large & Broad & Wide \\
\hline Ichnocarpus frutescens (L.) W.T.Aiton & Apocynaceae & $\mathrm{C}$ & PerTw & 62 & 0.40 & Large & Broad & Wide \\
\hline Imperata cylindrica (L.) Raeusch. & Poaceae & $\mathrm{H}$ & EA & 3,035 & 19.58 & Large & Broad & Wide \\
\hline Indigofera linifolia (L.f.) Retz. & Papilionaceae & $\mathrm{H}$ & PPer & 376 & 2.43 & Large & Broad & Wide \\
\hline Indigofera linnaei Ali & Papilionaceae & $\mathrm{H}$ & PPer & 47 & 0.30 & Small & Broad & Wide \\
\hline Ipomoea aquatica Forssk. & Convolvulaceae & $\mathrm{C}$ & ATw & 2 & 0.01 & Large & Broad & Wide \\
\hline Ipomoea pes-tigridis L. & Convolvulaceae & $\mathrm{C}$ & ATw & 5 & 0.03 & Small & Broad & Wide \\
\hline Ipomoea sp. & Convolvulaceae & $\mathrm{C}$ & ATw & 4 & 0.03 & Small & Broad & Wide \\
\hline Jatropha curcas L. & Euphorbiaceae & $\mathrm{S}$ & Eper & 11 & 0.07 & Small & Broad & Wide \\
\hline Kylinga brevifolia Rottb. & Cyperaceae & $\mathrm{H}$ & EA & 1,012 & 6.53 & Large & Broad & Wide \\
\hline Lantana camara $\mathrm{L}$ & Verbenaceae & $\mathrm{S}$ & EPer & 5 & 0.03 & Large & Broad & Wide \\
\hline Laphangium luteoalbum (L.) Tzvelev & Asteraceae & $\mathrm{H}$ & EA & 752 & 4.85 & Small & Broad & Wide \\
\hline Lathyrus aphaca $\mathrm{L}$. & Papilionaceae & $\mathrm{C}$ & ATn & 37 & 0.24 & Small & Broad & Wide \\
\hline Lathyrus odoratus L. & Papilionaceae & $\mathrm{C}$ & ATn & 44 & 0.28 & Small & Broad & Wide \\
\hline Lathyrus sativus L. & Papilionaceae & $\mathrm{C}$ & ATn & 13 & 0.08 & Small & Broad & Wide \\
\hline Launaea aspleniifolia (Willd.) Hook.f. & Asteraceae & $\mathrm{H}$ & EA & 396 & 2.55 & Small & Broad & Wide \\
\hline Launaea nudicaulis (L.) Hook.f. & Asteraceae & $\mathrm{H}$ & EA & 4 & 0.03 & Small & Broad & Wide \\
\hline Launaea procumbens (Roxb.) Ramayya \& Rajagopal & Asteraceae & $\mathrm{H}$ & EA & 6 & 0.04 & Small & Broad & Wide \\
\hline
\end{tabular}




\begin{tabular}{|c|c|c|c|c|c|c|c|c|}
\hline Plant species & Family & Habit & Posture & $\begin{array}{c}\text { Total no. } \\
\text { individuals }\end{array}$ & $\begin{array}{c}\text { Density } \\
\left(/ \mathrm{m}^{2}\right)\end{array}$ & $\begin{array}{l}\text { Population } \\
\text { size }\end{array}$ & $\begin{array}{c}\text { Habitat } \\
\text { specialization }\end{array}$ & $\begin{array}{c}\text { Geographical } \\
\text { range }\end{array}$ \\
\hline Leucas aspera (Willd.) Link & Lamiaceae & $\mathrm{H}$ & EA & 19 & 0.12 & Small & Broad & Narrow \\
\hline Leucas cephalotes (Roth) Spreng. & Lamiaceae & $\mathrm{H}$ & EA & 51 & 0.33 & Small & Broad & Narrow \\
\hline Limnophylla sp. 1 & Scrophulariaceae & $\mathrm{H}$ & EA & 4 & 0.03 & Small & Broad & Wide \\
\hline Limnophylla sp. 2 & Scrophulariaceae & $\mathrm{H}$ & EA & 11 & 0.07 & Small & Broad & Wide \\
\hline Limnophylla sp. 3 & Scrophulariaceae & $\mathrm{H}$ & EA & 40 & 0.26 & Small & Broad & Wide \\
\hline Lindernia antipoda (L.) Alston & Scrophulariaceae & $\mathrm{H}$ & EA & 182 & 1.17 & Small & Broad & Wide \\
\hline Lindernia brachiata (Link \& Otto) Biswas & Scrophulariaceae & $\mathrm{H}$ & EA & 22 & 0.14 & Large & Broad & Wide \\
\hline Lindernia ciliata (Colsm.) Pennell & Scrophulariaceae & $\mathrm{H}$ & EA & 8,761 & 56.52 & Large & Broad & Wide \\
\hline Lindernia crustacea (L.) F.Muell. & Scrophulariaceae & $\mathrm{H}$ & EA & 228 & 1.47 & Small & Broad & Wide \\
\hline Lindernia diffusa (L.) Wettst. & Scrophulariaceae & $\mathrm{H}$ & EA & 22,288 & 143.79 & Large & Broad & Wide \\
\hline Lindernia procumbens (Krock.) Philcox & Scrophulariaceae & $\mathrm{H}$ & PA & 108 & 0.70 & Large & Broad & Wide \\
\hline Lindernia pyxidaria All. & Scrophulariaceae & $\mathrm{H}$ & EA & 158 & 1.02 & Large & Narrow & Narrow \\
\hline Lippia alba (Mill.) N.E.Br. ex Britton \& P.Wilson & Verbenaceae & $\mathrm{S}$ & EA & 9 & 0.06 & Small & Broad & Wide \\
\hline Lobelia alsinoides Lam. & Lobeliaceae & $\mathrm{H}$ & EA & 141 & 0.91 & Small & Narrow & Narrow \\
\hline Ludwigia adscendens (L.) H.Hara & Onagraceae & $\mathrm{H}$ & PA & 1 & 0.01 & Small & Broad & Wide \\
\hline Ludwigia octovalvis (Jacq.) P.Raven & Onagraceae & $\mathrm{H}$ & EA & 10 & 0.06 & Small & Broad & Wide \\
\hline Ludwigia perennis L. & Onagraceae & $\mathrm{H}$ & EA & 176 & 1.14 & Small & Broad & Wide \\
\hline Ludwigia prostrata Roxb. & Onagraceae & $\mathrm{H}$ & EA & 9 & 0.06 & Small & Broad & Wide \\
\hline Malvastrum coromandelianum (L.) Garcke & Malvaceae & $\mathrm{H}$ & EA & 34 & 0.30 & Small & Broad & Wide \\
\hline Martynia annua $\mathrm{L}$. & Martyniaceae & $\mathrm{H}$ & EA & 10 & 0.06 & Small & Narrow & Narrow \\
\hline Mazus pumilus (Burm.f.) Steenis & Scrophulariaceae & $\mathrm{H}$ & EA & 129 & 0.83 & Large & Broad & Wide \\
\hline Mecardonia procumbens (Mill.) Small & Scrophulariaceae & $\mathrm{H}$ & EA & 168 & 1.08 & Small & Broad & Wide \\
\hline Medicago polymorpha L. & Papilionaceae & $\mathrm{H}$ & EA & 453 & 2.92 & Small & Broad & Wide \\
\hline Melochia corchorifolia $\mathrm{L}$. & Sterculiaceae & $\mathrm{H}$ & EA & 118 & 0.76 & Large & Broad & Wide \\
\hline Merremia sp. & Convolvulaceae & $\mathrm{H}$ & PA & 17 & 0.11 & Small & Broad & Wide \\
\hline Momordica dioica Roxb. ex Willd. & Cucurbitaceae & $\mathrm{C}$ & ATn & 3 & 0.02 & Small & Broad & Wide \\
\hline Mukia maderaspatana (L.) Roem. & Cucurbitaceae & $\mathrm{C}$ & ATn & 4 & 0.03 & Small & Broad & Wide \\
\hline Murdannia nudiflora (L.) Brenan & Commelinaceae & $\mathrm{H}$ & PA & 1,516 & 9.78 & Large & Broad & Wide \\
\hline Ocimum americanum $\mathrm{L}$. & Lamiaceae & $\mathrm{H}$ & EA & 55 & 0.35 & Large & Broad & Wide \\
\hline Oldenlandia biflora $\mathrm{L}$. & Rubiaceae & $\mathrm{H}$ & PA & 63 & 0.41 & Large & Broad & Wide \\
\hline Oldenlandia corymbosa $\mathrm{L}$. & Rubiaceae & $\mathrm{H}$ & PA & 1,315 & 8.48 & Large & Broad & Wide \\
\hline Oldenlandia tenelliflora (Blume) Kuntze & Rubiaceae & $\mathrm{H}$ & EA & 827 & 5.35 & Small & Broad & Wide \\
\hline Operculina turpethum (L.) Silva Manso & Convolvulaceae & $\mathrm{C}$ & PerTw & 8 & 0.05 & Large & Broad & Wide \\
\hline Oplismenus burmanni (Retz.) P.Beauv. & Poaceae & $\mathrm{H}$ & PA & 529 & 3.41 & Large & Broad & Wide \\
\hline Oxalis corniculata $\mathrm{L}$. & Oxalidaceae & $\mathrm{H}$ & PA & 92 & 0.59 & Large & Broad & Wide \\
\hline Oxystelma secamone H.Karst. & Asclepiadaceae & $\mathrm{C}$ & ATw & 2 & 0.01 & Small & Broad & Wide \\
\hline Panicum sumatrense Roth & Poaceae & $\mathrm{H}$ & EA & 20 & 0.13 & Small & Broad & Wide \\
\hline Panicum antidotale Retz. & Poaceae & $\mathrm{H}$ & EA & 74 & 0.48 & Large & Broad & Wide \\
\hline Panicum sp. 1 & Poaceae & $\mathrm{H}$ & $\mathrm{PA}$ & 125 & 0.81 & Large & Broad & Wide \\
\hline
\end{tabular}




\begin{tabular}{|c|c|c|c|c|c|c|c|c|}
\hline Plant species & Family & Habit & Posture & $\begin{array}{l}\text { Total no. } \\
\text { individuals }\end{array}$ & $\begin{array}{c}\text { Density } \\
\left(/ \mathrm{m}^{2}\right)\end{array}$ & $\begin{array}{c}\text { Population } \\
\text { size }\end{array}$ & $\begin{array}{c}\text { Habitat } \\
\text { specialization }\end{array}$ & $\begin{array}{l}\text { Geographical } \\
\text { range }\end{array}$ \\
\hline Panicum maximum Jacq. & Poaceae & $\mathrm{H}$ & EA & 296 & 1.91 & Large & Broad & Wide \\
\hline Panicum virgatum $\mathrm{L}$. & Poaceae & $\mathrm{H}$ & EA & 343 & 2.21 & Small & Broad & Wide \\
\hline Parthenium hysterophorus L. & Asteraceae & $\mathrm{H}$ & EA & 350 & 2.26 & Large & Broad & Wide \\
\hline Paspalidium flavidum (Retz.) A.Camus & Poaceae & $\mathrm{H}$ & PA & 1,311 & 8.46 & Large & Broad & Wide \\
\hline Paspalum distichum $\mathrm{L}$. & Poaceae & $\mathrm{H}$ & EPer & 672 & 4.34 & Small & Broad & Wide \\
\hline Paspalum scrobiculatum L. & Poaceae & $\mathrm{H}$ & EA & 1,679 & 10.83 & Large & Broad & Wide \\
\hline Pennisetum glaucum (L.) R.Br. & Poaceae & $\mathrm{H}$ & EA & 1,123 & 7.25 & Large & Broad & Wide \\
\hline Peristrophe bicalyculata (Retz.) Nees & Acanthaceae & $\mathrm{H}$ & EA & 41 & 0.26 & Large & Broad & Wide \\
\hline Perotis indica (L.) Kuntze & Poaceae & $\mathrm{H}$ & PA & 174 & 1.12 & Large & Narrow & Narrow \\
\hline Persicaria glabra (Willd.) M.Gómez & Polygonaceae & $\mathrm{H}$ & EA & 8 & 0.05 & Large & Broad & Wide \\
\hline Persicaria lapathifolia (L.) Delarbre & Polygonaceae & $\mathrm{H}$ & EA & 10 & 0.06 & Large & Broad & Wide \\
\hline Phyla nodiflora (L.) Greene & Verbenaceae & $\mathrm{H}$ & EA & 85 & 0.55 & Large & Broad & Wide \\
\hline Phyllanthus niruri L. & Euphorbiaceae & $\mathrm{H}$ & EA & 69 & 0.45 & Large & Broad & Wide \\
\hline Phyllanthus urinaria $\mathrm{L}$. & Euphorbiaceae & $\mathrm{H}$ & EA & 2,690 & 17.36 & Small & Broad & Wide \\
\hline Phyllanthus virgatus G.Forst. & Euphorbiaceae & $\mathrm{H}$ & EPer & 1,173 & 7.57 & Large & Broad & Wide \\
\hline Physalis minima $\mathrm{L}$. & Solanaceae & $\mathrm{H}$ & EA & 7 & 0.05 & Small & Broad & Wide \\
\hline Physalis peruviana $\mathrm{L}$. & Solanaceae & $\mathrm{H}$ & EA & 3 & 0.02 & Small & Broad & Wide \\
\hline Polygala chinensis $\mathrm{L}$. & Polygalaceae & $\mathrm{H}$ & EA & 94 & 0.61 & Small & Broad & Wide \\
\hline Polygonum plebeium $\mathrm{R} . \mathrm{Br}$. & Polygonaceae & $\mathrm{H}$ & PA & 286 & 1.85 & Large & Broad & Wide \\
\hline Portulaca oleracea L. & Portulacaceae & $\mathrm{H}$ & PA & 64 & 0.41 & Large & Broad & Wide \\
\hline Pouzolzia zeylanica (L.) Benn. & Urticaceae & $\mathrm{H}$ & EA & 19 & 0.12 & Large & Broad & Wide \\
\hline Pycreus pumilus (L.) Nees & Cyperaceae & $\mathrm{H}$ & EA & 30 & 0.19 & Small & Broad & Wide \\
\hline Ranunculus sceleratus L. & Ranunculaceae & $\mathrm{H}$ & EA & 4 & 0.03 & Large & Broad & Wide \\
\hline Rhynchospora colorata (L.) H.Pfeiff. & Cyperaceae & $\mathrm{H}$ & EA & 55 & 0.35 & Small & Broad & Wide \\
\hline Ruellia tuberosa L. & Acanthaceae & $\mathrm{H}$ & EA & 4 & 0.03 & Large & Broad & Wide \\
\hline Rumex hastatus D.Don. & Polygonaceae & $\mathrm{H}$ & EA & 199 & 1.28 & Large & Broad & Wide \\
\hline Rungia repens (L.) Nees & Acanthaceae & $\mathrm{H}$ & PA & 9,701 & 62.59 & Large & Broad & Wide \\
\hline Saccharum sp. & Poaceae & $\mathrm{H}$ & EA & 425 & 2.74 & Large & Broad & Wide \\
\hline Saccharum spontaneum L. & Poaceae & $\mathrm{H}$ & EPer & 76 & 0.49 & Large & Broad & Wide \\
\hline Sacciolepis indica (L.) Chase & Poaceae & $\mathrm{H}$ & EA & 144 & 0.93 & Large & Broad & Wide \\
\hline Sacciolepis myosuroides (R.Br.) A.Camus & Poaceae & $\mathrm{H}$ & EA & 79 & 0.51 & Large & Broad & Wide \\
\hline Salvia plebeia $\mathrm{R} . \mathrm{Br}$. & Lamiaceae & $\mathrm{H}$ & EA & 11 & 0.07 & Small & Broad & Wide \\
\hline Salvia reptans Jacq. & Lamiaceae & $\mathrm{H}$ & EA & 6 & 0.04 & Small & Broad & Wide \\
\hline Schoenoplectiella lateriflora (J.F.Gmel.) Lye & Cyperaceae & $\mathrm{H}$ & PA & 13 & 0.08 & Small & Broad & Wide \\
\hline Schoenoplectiella mucronata (L.) J.Jung \& H.K.Choi & Cyperaceae & $\mathrm{H}$ & EA & 13 & 0.08 & Small & Broad & Wide \\
\hline Scoparia dulcis $\mathrm{L}$. & Scrophulariaceae & $\mathrm{H}$ & EA & 172 & 1.11 & Large & Broad & Wide \\
\hline Senna obtusifolia (L.) H.S. Irwin \&Barneby & Caesalpiniaceae & $\mathrm{H}$ & EA & 606 & 3.91 & Large & Broad & Wide \\
\hline Senna occidentalis (L.) Link & Caesalpiniaceae & $\mathrm{H}$ & EA & 91 & 0.59 & Large & Broad & Wide \\
\hline Senna pumila (Lam.) K.Larsen & Caesalpiniaceae & $\mathrm{H}$ & PA & 13 & 0.08 & Large & Narrow & Narrow \\
\hline
\end{tabular}




\begin{tabular}{|c|c|c|c|c|c|c|c|c|}
\hline Plant species & Family & Habit & Posture & $\begin{array}{c}\text { Total no. } \\
\text { individuals }\end{array}$ & $\begin{array}{c}\text { Density } \\
\left(/ \mathrm{m}^{2}\right)\end{array}$ & $\begin{array}{l}\text { Population } \\
\text { size }\end{array}$ & $\begin{array}{c}\text { Habitat } \\
\text { specialization }\end{array}$ & $\begin{array}{l}\text { Geographical } \\
\text { range }\end{array}$ \\
\hline Senna tora (L.) Roxb. & Caesalpiniaceae & $\mathrm{H}$ & EA & 4 & 0.03 & Large & Broad & Wide \\
\hline Sida acuta Burm.f. & Malvaceae & $\mathrm{H}$ & EA & 191 & 1.23 & Large & Broad & Wide \\
\hline Sida cordata (Burm.f.) Borss.Waalk. & Malvaceae & $\mathrm{H}$ & EA & 185 & 1.19 & Large & Broad & Wide \\
\hline Sida cordifolia $\mathrm{L}$. & Malvaceae & $\mathrm{H}$ & EA & 182 & 1.17 & Large & Broad & Wide \\
\hline Sida ovata Forssk. & Malvaceae & $\mathrm{H}$ & EA & 7 & 0.05 & Large & Broad & Wide \\
\hline Sida rhombifolia $\mathrm{L}$. & Malvaceae & $\mathrm{H}$ & EA & 195 & 1.26 & Large & Broad & Wide \\
\hline Sida spinosa L. & Malvaceae & $\mathrm{H}$ & EA & 18 & 0.12 & Small & Broad & Wide \\
\hline Solanum americanum Mill. & Solanaceae & $\mathrm{H}$ & EA & 23 & 0.15 & Large & Broad & Wide \\
\hline Solanum virginianum L. & Solanaceae & $\mathrm{H}$ & EA & 1 & 0.01 & Large & Broad & Wide \\
\hline Soliva anthemifolia (Juss.) Sweet & Asteraceae & $\mathrm{H}$ & PA & 4 & 0.03 & Small & Broad & Wide \\
\hline Sonchus asper (L.) Hill & Asteraceae & $\mathrm{H}$ & EA & 11 & 0.07 & Large & Broad & Wide \\
\hline Sonchus oleraceus (L.) L. & Asteraceae & $\mathrm{H}$ & EA & 3 & 0.02 & Small & Broad & Wide \\
\hline Spermacoce pusilla Wall. & Rubiaceae & $\mathrm{H}$ & EA & 4,076 & 26.30 & Large & Narrow & Narrow \\
\hline Sphenoclea zeylanica Gaertn. & Sphenocleaceae & $\mathrm{H}$ & EA & 10 & 0.06 & Small & Narrow & Narrow \\
\hline Spilanthes acmella (L.) L. & Asteraceae & $\mathrm{H}$ & PA & 31 & 0.20 & Large & Broad & Wide \\
\hline Tecoma capensis (Thunb.) Lindl. & Bignoniaceae & $\mathrm{C}$ & PerTw & 3 & 0.02 & Small & Broad & Wide \\
\hline Tephrosia purpurea (L.) Pers. & Papilionaceae & $\mathrm{H}$ & EPer & 6 & 0.04 & Large & Broad & Wide \\
\hline Teramnus labialis (L.f.) Spreng. & Papilionaceae & $\mathrm{C}$ & PerTw & 8 & 0.05 & Small & Narrow & Narrow \\
\hline Tiliacora racemosa Colebr. & Menispermaceae & $\mathrm{C}$ & PerTw & 1 & 0.01 & Large & Broad & Wide \\
\hline Tinospora sinensis (Lour.) Merr. & Menispermaceae & $\mathrm{C}$ & PerTw & 9 & 0.06 & Large & Broad & Wide \\
\hline Trianthema portulacastrum L. & Aizoaceae & $\mathrm{H}$ & PA & 8 & 0.05 & Small & Broad & Wide \\
\hline Tribulus terrestris L. & Zygophyllaceae & $\mathrm{H}$ & PA & 5 & 0.03 & Small & Narrow & Narrow \\
\hline Tridax procumbens (L.) L. & Asteraceae & $\mathrm{H}$ & EA & 603 & 3.89 & Large & Broad & Wide \\
\hline Triumfetta pentranda A.Rich. & Malvaceae & $\mathrm{H}$ & EA & 31 & 0.20 & Large & Broad & Wide \\
\hline Triumfetta rhomboidea Jacq. & Malvaceae & $\mathrm{S}$ & EA & 18 & 0.12 & Large & Broad & Wide \\
\hline Urena lobata $\mathrm{L}$. & Malvaceae & $\mathrm{S}$ & EA & 5 & 0.03 & Large & Broad & Wide \\
\hline Urena repanda Roxb. ex Sm. & Malvaceae & $\mathrm{H}$ & EA & 35 & 0.23 & Large & Broad & Wide \\
\hline Vernonia sp. & Asteraceae & $\mathrm{H}$ & EA & 9 & 0.06 & Small & Narrow & Narrow \\
\hline Xanthium strumarium L. & Asteraceae & $\mathrm{S}$ & EA & 79 & 0.51 & Large & Broad & Wide \\
\hline Zephyranthes citrina Baker & Amaryllidaceae & $\mathrm{H}$ & EA & 8 & 0.05 & Small & Narrow & Narrow \\
\hline Zornia gibbosa Span. & Papilionaceae & $\mathrm{H}$ & PA & 3,255 & 21.00 & Small & Broad & Wide \\
\hline \multicolumn{9}{|c|}{ Samples in process of species identification: } \\
\hline Unknown 3 & Poaceae & $\mathrm{H}$ & EA & 679 & 4.38 & Small & Broad & Wide \\
\hline Unknown 4 & Poaceae & $\mathrm{H}$ & EA & 1,270 & 8.19 & Large & Broad & Wide \\
\hline Unknown 5 & Poaceae & $\mathrm{H}$ & EA & 620 & 4 & Large & Broad & Wide \\
\hline Unknown 6 & Poaceae & $\mathrm{H}$ & EA & 36 & 0.23 & Small & Broad & Wide \\
\hline Unknown 7 & Poaceae & $\mathrm{H}$ & EA & 170 & 1.07 & Small & Broad & Wide \\
\hline Unknown 8 & Poaceae & $\mathrm{H}$ & EA & 57 & 0.37 & Large & Broad & Wide \\
\hline Unknown 9 & Poaceae & $\mathrm{H}$ & EA & 311 & 2.01 & Small & Broad & Wide \\
\hline
\end{tabular}




\begin{tabular}{|c|c|c|c|c|c|c|c|c|}
\hline Plant species & Family & Habit & Posture & $\begin{array}{c}\text { Total no. } \\
\text { individuals }\end{array}$ & $\begin{array}{c}\text { Density } \\
\left(/ \mathrm{m}^{2}\right)\end{array}$ & $\begin{array}{l}\text { Population } \\
\text { size }\end{array}$ & $\begin{array}{c}\text { Habitat } \\
\text { specialization }\end{array}$ & $\begin{array}{c}\text { Geographical } \\
\text { range }\end{array}$ \\
\hline Unknown 10 & Poaceae & $\mathrm{H}$ & EA & 18 & 0.12 & Small & Broad & Wide \\
\hline Unknown 11 & Poaceae & $\mathrm{H}$ & EA & 340 & 2.19 & Small & Broad & Wide \\
\hline Unknown 12 & Poaceae & $\mathrm{H}$ & EA & 67 & 0.43 & Large & Broad & Wide \\
\hline Unknown 13 & Poaceae & $\mathrm{H}$ & EA & 11 & 0.07 & Large & Broad & Wide \\
\hline Unknown 14 & Poaceae & $\mathrm{H}$ & EA & 95 & 0.61 & Small & Broad & Wide \\
\hline Unknown 15 & Poaceae & $\mathrm{H}$ & EA & 19 & 0.12 & Small & Broad & Wide \\
\hline Unknown 16 & Poaceae & $\mathrm{H}$ & EA & 72 & 0.46 & Large & Broad & Wide \\
\hline Unknown 17 & Poaceae & $\mathrm{H}$ & EA & 36 & 0.23 & Large & Broad & Wide \\
\hline Unknown 18 & Poaceae & $\mathrm{H}$ & EA & 151 & 0.97 & Large & Broad & Wide \\
\hline Unknown 19 & Unknown & $\mathrm{H}$ & EA & 3 & 0.02 & Small & Broad & Wide \\
\hline Unknown 20 & Papilionaceae & $\mathrm{H}$ & PA & 25 & 0.16 & Small & Broad & Wide \\
\hline Unknown 21 & Unknown & $\mathrm{C}$ & ATw & 4 & 0.03 & Small & Broad & Wide \\
\hline Unknown 22 & Papilionaceae & $\mathrm{C}$ & ATw & 2 & 0.01 & Small & Broad & Wide \\
\hline Unknown 23 & Papilionaceae & $\mathrm{C}$ & ATw & 8 & 0.05 & Large & Broad & Wide \\
\hline Unknown 24 & Asteraceae & $\mathrm{H}$ & EA & 4 & 0.03 & Large & Broad & Wide \\
\hline Unknown 25 & Papilionaceae & $\mathrm{C}$ & ATw & 2 & 0.01 & Large & Broad & Wide \\
\hline Unknown 27 & Acanthaceae & $\mathrm{H}$ & EA & 17 & 0.11 & Small & Broad & Wide \\
\hline Unknown 28 & Unknown & $\mathrm{H}$ & EA & 5 & 0.03 & Large & Broad & Wide \\
\hline Unknown 29 & Unknown & $\mathrm{H}$ & PA & 4 & 0.03 & Small & Broad & Wide \\
\hline Unknown 30 & Unknown & $\mathrm{H}$ & EA & 2 & 0.01 & Small & Broad & Wide \\
\hline
\end{tabular}

(Received for publication 31 January 2015; accepted 10 August 2015)

(C) 2015

\section{(c) (1) (2) (2)}

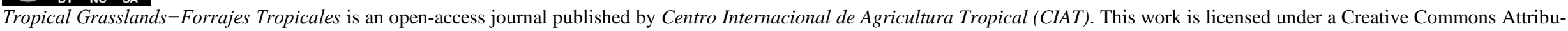
tion-NonCommercial-ShareAlike 3.0 Unported License. To view a copy of this license, visit http://creativecommons.org/licenses/by-nc-sa/3.0/ 